\title{
PERSEPSI PETANI TERHADAP PERAN PENYULUH PERTANIAN DI DESA RASI KECAMATAN RATAHAN KABUPATEN MINAHASA TENGGARA
}

\author{
Meksy V. G. Timbulus \\ Mex L. Sondakh \\ Grace A.J. Rumagit
}

\begin{abstract}
ABSRACT
The purpose of this study was to determine the perception of the role of farmers in the village agricultural extension Rasi, District Ratahan, Southeast Minahasa Regency. The study was implemented for 4 months, namely from March to June 2016. This study uses primary data and secondary data. The primary data obtained through interviews with farmers based on a list of questions (questionnaire), while secondary data obtained from the Office of Agricultural Extension Agency for Fisheries and Forestry (BP3K), District Ratahan, Southeast Minahasa Regency. The sampling method in this study is using a non-probability. Analysis of data using a Likert Scale based on the answers of 25 questions to measure the perception of the role of farmers to extension workers with total respondents as many as 36 people. These results indicate that the total score of the level of farmers' perceptions of the role of agricultural extension for 3678 and are in the perception index of 81 percent, thus the perception of farmers as very good. Perception is in excellent farmers also on an indicator of increased productivity results, level of innovation ease of extension can be easily put into practice, the results of innovation extension can be easily seen or observed, productivity increased output is larger than before farmers using agricultural extension innovation.
\end{abstract}

Keywords: perception of farmers, agricultural extension, Rasi Villagei, Southeast Minahasa District

\begin{abstract}
ABSTRAK
Tujuan dari penelitian ini adalah untuk mengetahui persepsi petani terhadap peran penyuluh pertanian di Desa Rasi, Kecamatan Ratahan, Kabupaten Minahasa Tenggara. Penelitian ini di laksanakan selama 4 bulan yaitu dari bulan Maret sampai dengan Juni tahun 2016. Penelitian ini menggunakan data primer dan data sekunder. Data primer diperoleh melalui wawancara langsung dengan petani berdasarkan daftar pertanyaan (kuesioner), sedangkan data sekunder diperoleh dari Kantor Badan Penyuluh Pertanian Perikanan dan Kehutanan (BP3K), Kecamatan Ratahan, Kabupaten Minahasa Tenggara. Metode pengambilan sampel dalam penelitian ini menggunakan metode non-probabilitas. Analisis data menggunakan Skala Likert yang didasarkan pada jawaban dari 25 pertanyaan untuk mengukur persepsi petani terhadap peran penyuluh dengan total responden sebanyak 36 orang. Hasil penelitian ini menunjukan bahwa total skor tingkat persepsi petani mengenai peran penyuluh pertanian sebesar 3678 dan berada pada indeks persepsi 81 persen, dengan demikian persepsi petani tergolong sangat baik. Persepsi petani tergolong sangat baik juga pada indikator peningkatan produktifitas hasil, tingkat kemudahan inovasi penyuluh dapat dengan mudah dipraktekkan, hasil inovasi penyuluh dapat dengan mudah terlihat atau diamati, produktifitas hasil yang meningkat tersebut lebih besar dari sebelum petani menggunakan inovasi penyuluh pertanian.
\end{abstract}

Kata kunci: persepsi petani, penyuluh pertanian, Desa Rasi, Kabupaten Minahasa Tenggara

\section{PENDAHULUAN}

\section{Latar Belakang}

Penyuluhan merupakan keterlibatan seseorang untuk melakukan komunikasi informasi secara sadar dengan tujuan membantu sasarannya memberikan pendapat sehingga dapat membuat keputusan yang benar. Kegiatan tersebut dilakukan oleh seseorang yang disebut penyuluh pertanian (Van Den Ban dan Hawkins, 1999). Hal ini sesuai dengan pernyataan Kartasapoetra (1994) menyatakan bahwa penyuluh pertanian merupakan agen bagi perubahan perilaku petani, yaitu mendorong petani mengubah perilakunya menjadi 
petani dengan kemampuan yang lebih baik dan mampu mengambil keputusan sendiri, yang selanjutnya akan memperoleh kehidupan yang lebih baik.

Dari uraian di atas maka tujuan penyuluhan adalah mengubah perilaku petani melalui peningkatan pengetahuan, sikap, ketrampilan serta motivasi petani sasarannya sehingga petani mampu untuk mengambil keputusan dalam mejalankan dan mengembangkan usaha taninya secara mandiri. Melalui peran penyuluh, petani diharapkan menyadari akan kebutuhannya, melakukan peningkatan kemampuan diri, dan dapat berperan di masyarakat dengan lebih baik.

Mencermati hal di atas, maka dalam kegiatan penyuluhan, peran seorang penyuluh pertanian sangat diperlukan dalam upaya mendorong terjadinya perubahan perilaku petani sasaran sesuai dengan yang dikehendaki. Dengan kata lain, keberhasilan suatu penyuluhan sangat dipengaruhi oleh besarnya peran penyuluh yang diberikan melalui kegiatan penyuluhan.Mosher (1997), menguraikan tentang peran penyuluh pertanian, yaitu: sebagai guru, penganalisa, penasehat, sebagai organisator, sebagai pengembang kebutuhan perubahan, penggerak perubahan, dan pemantap hubungan masyarakat petani. Berdasarkan perannya tersebut maka secara empiris penyuluh pertanian merupakan ujung tombak keberhasilan pembangunan pertanian (Hubeis et al.1998),

Salah satu langkah efektif yang dapat ditempuh dalam rangka mempercepat laju proses pembangunan pertanian adalah dengan melakukan pengembangan petani. Kelompok tani sangat penting dalam proses penyampaian informasi dan teknologi baru kepada petani. Metode penyuluhan kelompok lebih menguntungkan dari pada media masa karena akan terjadi umpan balik yang dapat meminimalkan salah pengertian antara penyuluh dan petani dalam penyampaian informasi. Dalam metode ini interaksi yang timbul antara petani dan penyuluh akan lebih intensif. Dalam metode ini petani diajak dan dibimbing secara berkelompok untuk melaksanakan kegiatan yang lebih produktif atas dasar kerja sama.

Permentan Nomor: 273/Kpts/OT.160/4/2007, menyebutkan ada tiga arah pengembangan kelompok tani, yaitu: (1) Peningkatan kemampuan kelompok tani dalam melaksanakan fungsinya (wadah belajar, wahana kerjasama dan unit produksi); (2) Peningkatan kemampuan para anggota dalam mengembangkan agribisnis; dan (3) Menguatkan kelompok tani menjadi organisasi petani yang kuat dan mandiri.
Seperti yang telah diuraikan di atas, maka dalam upaya pengembangan kelompok tani sangat membutuhkan atau tergantung pada kemampuan penyuluh dalam memainkan perannya sehingga proses pengembangan kelompok tani dapat sesuai dengan arah pengembangan kelompok tani sebagaimana yang disebutkan dalam Permentan. Dengan kata lain, dapat dikatakan bahwa tinggi rendahnya tingkat perkembangan kelompok tani sangat dipengaruhi oleh besarnya peran penyuluh yang diberikan dalam melakukan pengembangan terhadap kelompok tani.

Desa Rasi merupakan desa yang terletak di Kecamatan Ratahan Kabupaten Minahasa Tenggara. Sebagian besar penduduk di desa ini berprofesi sebagai petani, Kelompok tani di desa ini berjumlah 9 Kelompok tani yang berjumlah 180 petani, jumlah penyuluh yang mengkoordinir kelompok tani di Desa Rasi berjumlah 1 orang. Melalui penyuluhan pertanian yang diadakan, pemerintah juga sudah berusaha untuk memberi bantuan dengan memberikan penyuluhan lewat parah penyuluh tentang cara bertani yang baik dan benar kepada para kelompok tani di Desa Rasi ini beserta dengan manfaat dan kelebihannya.

Persepsi yang terbentuk dalam diri petani akan mempengaruhi cara pandangnya terhadap manfaat dan keunggulan peran penyuluh. Persepsi petani terhadap keunggulan peran penyuluh dapat menjadi salah satu faktor penghambat atau pendorong bagi petani dalam pengembangan petani. Untuk itu perlu di kaji tentang persepsi petani terhadap peran penyuluh.

\section{Rumusan Masalah}

Berdasarkan latar belakang permasalahan diatas, maka perumusan masalah dalam penelitian ini adalah bagaimana persepsi petani terhadap peran penyuluh di Desa Rasi Kecamatan Ratahan.

\section{Tujuan Penelitian}

Tujuan dari penelitian ini adalah untuk mengetahui persepsi petani terhadap peran penyuluh di Desa Rasi Kecamatan Ratahan.

\section{Manfaat Penelitian}

Manfaat dari penelitian ini adalah dapat menjadi bahan informasi dan bahan pertimbangan bagi pemerintah dalam memberikan penyuluhan kepada petani. Agar bisa bertani dengan baik dan benar. Bagi petani juga dapat menjadi bahan pertimbangan dalam pengembangan petani di Desa Rasi ini. Serta sebagai sarana mengembangkan pola pikir, menambah pengalaman bagi peneliti. 


\section{METODOLOGI PENELITIAN}

\section{Waktu dan Tempat Penelitian}

Penelitian ini di laksanakan selama 4 bulan yaitu dari bulan Maret sampai dengan Juni tahun 2016, mulai dari persiapan sampai penyusunan laporan penelitian. Bertempat di Desa Rasi, Kecamatan Ratahan. Penentuan lokasi penelitian berdasarkan pada desa yang memiliki jumlah kelompok tani paling banyak.

\section{Metode Pengumpulan Data}

Metode yang digunakan dalam penelitian ini adalah metode survey, Penelitian ini menggunakan data primer dan data sekunder. Data primer diperoleh melalui wawancara langsung dengan petani berdasarkan daftar pertanyaan (kuesioner), sedangkan data sekunder diperoleh dari formatKepala BP3K (badan penyuluh pertanian perikanan dan kehutanan) Kecamatan Ratahan, Kabupaten Minahasa Tenggara.

\section{Metode Pengambilan Sampel}

Metode pengambilan sampel dalam penelitian ini menggunakan metode nonprobabilitas,

\section{Konsepsi Pengukuran Variabel}

1. Karakteristik petani, yaitu beberapa ciri petani:

a. Jenis kelamin

b. Tingkat pendidikan (SD, SMP, SMA, S1)

c. Umur: jumlah usia sejak responden dilahirkan sampai saat menjadi responden dalam penelitian (tahun)

2. Pengukuran yang diambil untuk mengukur persepsi petani terhadap peran penyuluh adalah metode self reportyang merupakan suatu metode yang dapat mengukur sikap seseorang terhadap objek yang di teliti dalam hal ini penyuluh.Menurut Rogers, E.M. (1983) dalamEdwina, S. dan Evi Maharani (2010), persepsi petani terhadap peran penyuluh, yaitu penilaian dan pernyataan responden tentang peran penyuluh, yang meliputi :

a. Keuntungan Relatif (relative advance), adalah tingkatan dimana suatu ide baru dapat dianggap suatu yang lebih baik dari pada ideide yang ada sebelumnya dan secara ekonomis menguntungkan.

b. Tingkat Kesesuaian (compatibility), menunjukan kesesuaian inovasi peran penyuluh dengan nilai-nilai, kepercayaan masyarakat, kebiasaan yang telah ada, pengalaman sebelumnya dan kebutuhan petani.

c. Tingkat Kerumitan (complexity), menggambarkan tingkat kesukaran dari inovasi peran penyuluh. Indikator tingkat kerumitan adalah Tingkat kesukaran memahami inovasidan melaksanakan inovasi tersebut.

d. Tingkat Kemudahan untuk Dicoba (triability), menggambarkan derajat kemungkinan saran penyuluh untuk dicoba.

e. Tingkat Kemudahan untuk Dilihat Hasilnya (observability), menggambarkan derajat kemungkinan hasil inovasi dari penggunaan saran penyuluh dapat diamati.

\section{Analisis Data}

Pertanyaan untuk mengukur persepsi petani terhadap peran penyuluh di Desa Rasi yaitu total sebanyak 25 pertanyaan dengan total responden 36 orang. Setiap jawaban dihubungkan dengan bentuk pernyataan atau dukungan sikap yang diungkapkan dengan kata-kata berikut (Riduwan, 2008)

$\begin{array}{lll}\text { SS } & \text { : Sangat Setuju } & \text { Skor: 5 } \\ \text { S } & \text { : Setuju } & \text { Skor: 4 } \\ \text { RR } & \text { : Ragu-Ragu } & \text { Skor: 3 } \\ \text { TS } & \text { : Tidak Setuju } & \text { Skor: 2 } \\ \text { STS } & \text { : Sangat Tidak Setuju } & \text { Skor: 1 }\end{array}$

Dengan cara perhitungan skor sebagai berikut:

\section{Jumlah Skor Tiap Kriterium = Capaian Skor X Jumlah Responden}

Untuk:

$$
\begin{aligned}
& S_{5}=5 \times 36=180 \\
& S_{4}=4 \times 36=144 \\
& S_{3}=3 \times 36=108 \\
& S_{2}=2 \times 36=72 \\
& S_{1}=1 \times 36=36
\end{aligned}
$$

Jumlah skor ideal untuk setiap item pertanyaan (skor tertinggi) $=180$ (Sangat setuju)

Jumlah skor terendah $=36$ (Sangat tidak setuju) 


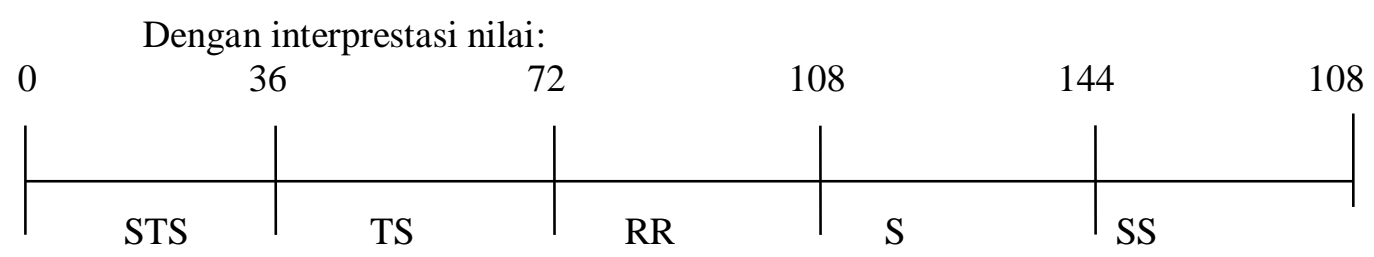

Cara perhitungan skor keseluruhan untuk mengetahui tingkat persepsi petani terhadap peran penyuluh:

\section{Jumlah Skor Seluruh Kriterium $=$ Capaian Jumlah Skor $\mathbf{X}$ Jumlah Responden $\mathbf{X}$ Jumlah pertanyaan}

Untuk:

$$
\begin{aligned}
& S_{5}=5 \times 36=180 \times 25=4500 \\
& S_{4}=4 \times 36=144 \times 25=3600 \\
& S_{3}=3 \times 36=108 \times 25=2700 \\
& S_{2}=2 \times 36=72 \times 25=1800 \\
& S_{1}=1 \times 36=36 \times 25=900
\end{aligned}
$$

Jumlah skor ideal untuk keseluruhan pertanyaan $=4500$ (Sangat setuju)

Jumlah skor terendah $=900$ (Sangat tidak setuju)

Dengan interpretasi nilai:

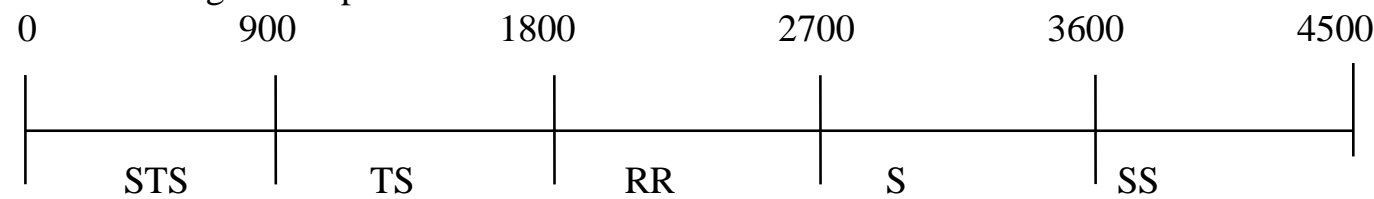

Analisis data yang digunakan merupakan analisis deskriptif yang dianalisis dengan menggunakan likert scale (skala likert) dimana menurut Riduwan (2008) dalam buku rumus dan data dalam analisis statistika sebagai berikut :

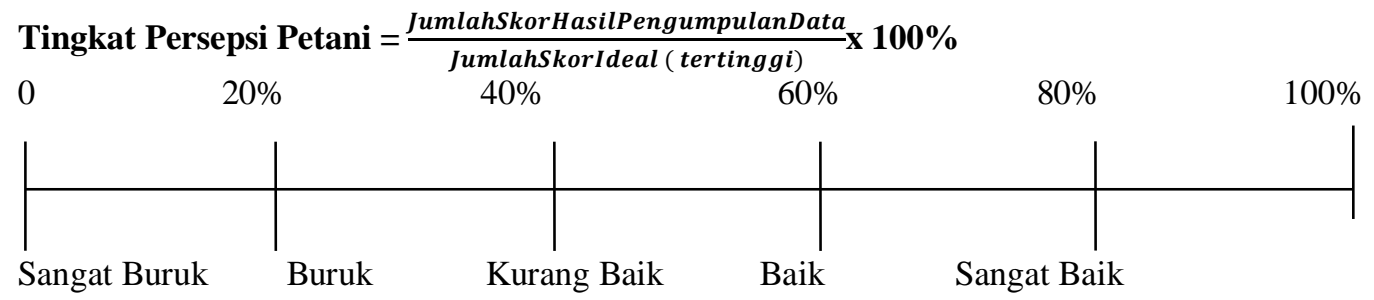

Keterangan : Kriteria interpretasi skor

$$
\begin{array}{ll}
\text { Angka 0\%-20\% } & =\text { Sangat buruk } \\
\text { Angka 21\%-40\% } & =\text { Buruk } \\
\text { Angka 41\%-60\% } & =\text { Kurang baik } \\
\text { Angka 61\%-80\% } & =\text { Baik } \\
\text { Angka } 81 \%-100 \% & =\text { Sangat baik }
\end{array}
$$

\section{HASIL DAN PEMBAHASAN}

\section{Persepsi Petani Terhadap Peran Penyuluh Pertanian}

Persepsi petani terhadap peran penyuluh pertanian dalam penelitian ini terdiri dari lima butir inovasi, yaitu: 1) persepsi terhadap keuntungan relatif (manfaat ekonomis, manfaat/kelebihan teknis), 2) persepsi petani terhadap tingkat kesesuaiaan (kondisi lingkungan, adat istiadat, kebutuhan petani), persepsi petani terhadap tingkat kemudahan untuk dicoba, 3) persepsi petani terhadap tingkat kemudahan untuk dilihat hasilnya (produksi atau hasil, kualitas produksi atau mutu). Skala yang digunakan untuk melihat persepsi petani terhadap peran penyuluh pertanian adalah Skala Likert. 


\section{Persepsi Petani terhadap Keuntungan Relatif (Relative Advance)}

Keuntungan relatif suatu inovasi adalah tingkatan dimana suatu ide baru dapat dianggap suatu hal yang lebih baik dari pada ide-ide yang ada sebelumnya, dan secara ekonomis menguntungkan. Keuntungan relative dibedakan menjadi dua macam, yaitu 1) manfaat ekonomis adalah keuntungan atau pendapatan yang diperoleh dengan adanya inovasi, 2) manfaat/kelebihan teknis adalah keuntungan dari peningkatan hasil panen, dan 3) manfaat bagi peningkatan kesejahteraan petani. Penggunaan peran penyuluh (inovasi atau ide baru) terlaksana apabila inovasi atau peran penyuluh dapat memberikan keuntungan yang lebih baik dibanding sebelum petani menggunakan inovasi penyuluh, dalam hal ini terjadi peningkatan produktifitas hasil usahatani, peningkatan pendapatan dan peningkatan kesejahteraan bagi petani yang menggunakannya.

\section{Persepsi Petani terhadap Peran Penyuluh mengenai Petani Mendapatkan Ide Baru Guna untuk di Terapkan dalam Usaha Taninya}

Tabel 1 menunjukan persepsi petani mengenai petani mendapatkan ide baru guna untuk diterapkan dalam usaha taninya. Tabel 1 menunjukan bahwa sebagian besar responden, yaitu $21(58,3 \%)$ petani sangat setuju, serta terdapat $15(41,6 \%)$ yang setuju bahwa para petani mendapatkan ide baru guna untuk diterapkan dalam usaha taninya. Dalam indikator ini, total skor persepsi petani sebesar $165 / 180 \times 100 \%=91,6 \%$, sehingga interpretasi nilainya tergolong sangat baik. Hal yang melatarbelakangi persepsi petani sangat baik terhadap penyuluh dalam hal ini petani mendapatkan ide baru dalam usaha taninya adalah menurut wawancara saya dengan responden atau petani banyak hal yang mereka bisa dapatkan dari penyuluh untuk diterapkan dalam usaha taninya misalnya cara pengolahan tanah dan menanam yang baik dan benar, anjuran penyuluh untuk petani agar menggunakan bibit varietas unggul, penggunaan pupuk dan cara pemeliharaan tanaman lainnya.

Tabel 2 menunjukan persepsi petani mengenai ide baru yang didapat petani dapat meningkatkan pendapatan petani. Tabel 2 menunjukan bahwa persepsi petani mengenai ide baru yang didapatkan petani dapat meningkatkan pendapatan.

\section{Persepsi Petani terhadap Peran Penyuluh mengenai Ide Baru yang Didapat Petani Dapat Meningkatkan Pendapatan Petani}

Tabel 2 menunjukan bahwa sebagian besar responden, yaitu $19(52,7)$ setuju, serta 14 $(38,8)$ petani sangat setuju bahwa ide baru yang didapat petani dapat meningkatkan pendapatan petani dan terdapat 2 atau $(5,5 \%)$ yang merasa ragu-ragu bahwa ide baru yang didapat petani bisa meningkatkan pendapatan. Dalam indikator ini, total skor persepsi petani sebesar 152/180 x $100 \%=84,4 \%$, sehingga interpretasi nilainya tergolong sangat baik. Hal yang melatarbelakangi persepsi petani sangat baik terhadap peran penyuluh dalam hal ini ide baru yang didapat petani dari penyuluh dapat meningkatkan pendapatan adalah menurut wawancara saya dengan petani dengan penggunaan saran, ide baru, dan inovasi dari penyuluh para petani bisa mendapatkan peningkatan pendapatan karna penggunaan varietas unggul, dan pengunaan pupuk yang disarankan oleh para penyuluh pertanian.

\section{Persepsi Petani terhadap Peran Penyuluh mengenai dengan Meningkatnya Pendapatan dapat juga Meningkatkan Kesejahteraan Petani.}

Tabel 3 menunjukan persepsi petani mengenai dengan meningkatnya pendapatan dapat juga meningkatkan kesejahteraan petani. Tabel 3 menunjukan bahwa sebagian besar resonden, yaitu $18(50 \%)$ sangat setuju, serta terdapat $18(50 \%)$, yang setuju bahwa dengan meningkatnya pendapatan dapat juga meningkatkan kesejahteraan petani. Dalam indikator ini, total skor persepsi petani sebesar $162 / 180 \times 100 \%=90 \%$, sehingga interpretasi nilainya tergolong sangat baik. Hal yang melatarbelakangi sehingga persepsi petani sangat baik terhadap peran penyuluh dalam hal ini dengan meningkatnya pendapatan dapat juga meningkatkan kesejahteraan petani adalah menurut wawancara saya dengan petani sebagian besar dari mereka berpendapat bahwa kalau pendapatan meningkat otomatis kesejahteraanpun meningkat, tapi ada juga para petani yang berpendapat bahwa tidak semua petani sama atau berpendapat sama karna 
menurut mereka ada juga petani yang walaupun pendapatan mereka meningkat setelah menggunakan saran,inovasi atau ide baru dari penyuluh pertanian, mereka tidak merasakan kesejahteraan dalam keluarga mereka ( keluarga tani ), karena taraf kesejahteraan petani satu dengan yang lain berbeda-beda.

\section{Persepsi Petani terhadap Peran Penyuluh mengenai dengan meningkatnya Kesejahteraan Petani Bisa Menyekolahkan Anak}

Tabel 4 menunjukan persepsi petani mengenai dengan meningkatnya kesejahteraan, petani bisa menyekolakan anak. Tabel 4 menunjukan bahwa sebagian besar responden, yaitu $20(55,5 \%)$ setuju, serta terdapat 16 atau $(44,4 \%)$ responden yang sangat setuju bahwa dengan meningkatnya kesejahteraan petani bisa menyekolahkan anak. Dalam indikator ini, total skor persepsi petani sebesar 160/180 x 100\%= $88,8 \%$, sehingga interpretasi nilainya tergolong sangat baik. Hal yang melatarbelakangi persepsi petani sangat baik terhadap peran penyuluh dalam hal ini dengan meningkatnya kesejahteraan, petani bisa menyekolahkan anak adalah menurut wawancara saya dengan petani dilapangan sebagian besar mereka mengatakan bahwa yah memang saya menyekolahkan anak saya sampai sarjana hanya dengan bertani.

\section{Persepsi Petani terhadap Peran Penyuluh mengenai dengan Meningkatnya Pendapatan \\ Bapak atau Ibu bisa membuat Tabungan (saving) untuk Keluarga}

Tabel 5 menunjukan persepsi petani mengenai dengan meningkatnya pendapatan bapak atau ibu bisa membuat tabungan (saving) untuk keluarga. Tabel 5 menunjukan bahwa sebagian besar responden, yaitu 29 (80,5\%) setuju, serta terdapat 6 atau $(16,6 \%)$ sangat setuju, dan ada juga $1(2,7 \%)$ responden yang menjawab ragu-ragu bahwa dengan meingkatnya pendapatan bapak atau ibu bisa membuat tabungan (saving) untuk keluarga. Dalam indikator ini, total skor persepsi petani sebesar 149/180 x 100\% $=82,7 \%$, sehingga interpretasi nilainya tergolong sangat baik. Menurut wawancara saya dengan petani dilapangan hal yang melatarbelakangi persepsi petani terhadap peran penyuluh sangat baik dalam hal ini dengan meningkatnya pendapatan bapak atau ibu bisa membuat tabungan atau (saving) adalah sebagian besar petani berpendapat bahwa karna saran, inovasi, dan ide baru dari penyuluh pertanian sehingga petani bisa meningkatkan pendapatan dan juga untuk membuat tabungan (saving).

\section{Rekapitulasi Persepsi Petani Terhadap Keuntungan Relatif (Relative Advance)}

Tabel 6 menunjukan 5 pernyataan tentang persepsi petani terhadap keuntungan relative (Relative advance). Pernyataan dengan jumlah indeks tertiggi adalah pernyataan 1 yaitu 91,6 selanjutnta pernytaan 3 yaitu 90, selanjutnya pernyataan 4 yaitu 88,8 selanjutnya pernyataan 2 yaitu 84,4 dan pernyataan 5 yaitu 82,7 .

\section{Persepsi Petani terhadap Tingkat Kesesuaian (compatibility)}

Persepsi petani mengenai tingkat kesesuaiaan terhadap penggunaan peran penyuluh pertanian dibedakan menjadi tiga macam, yaitu 1) adat istiadat, yaitu tata cara, nilai budaya atau kebiasaan petani dalam bercocok tanam, dan 2) kebutuhan petani, yaitu keinginan yang menjadi tuntutan bagi petani agar dapat tetap menjalankan usaha taninya.

Tabel 1. Petani mendapatkan ide baru guna untuk diterapkan dalam usaha taninya

\begin{tabular}{ccccc}
\hline $\begin{array}{c}\text { Alternatif } \\
\text { Jawaban }\end{array}$ & $\begin{array}{c}\text { Alternatif } \\
\text { Skor }\end{array}$ & $\begin{array}{c}\text { Jumlah } \\
\text { Responden } \\
\text { (orang) }\end{array}$ & $\begin{array}{c}\text { Persentase } \\
\text { Responden } \\
(\%)\end{array}$ & $\begin{array}{c}\text { Total } \\
\text { Skor }\end{array}$ \\
\hline Sangat Setuju & 5 & 21 & 58,3 & 105 \\
Setuju & 4 & 15 & 41,6 & 60 \\
Ragu-Ragu & 3 & - & - & - \\
Tidak Setuju & 2 & - & - & - \\
Sangat Tidak Setuju & 1 & - & - & 165
\end{tabular}

Sumber: Diolah dari Data Primer, 2016 
Tabel 2. Ide Baru yang didapat Petani dapat Meningkatkan Pendapatan Petani

\begin{tabular}{ccccc}
\hline $\begin{array}{c}\text { Alternatif } \\
\text { Jawaban }\end{array}$ & $\begin{array}{c}\text { Alternatif } \\
\text { Skor }\end{array}$ & $\begin{array}{c}\text { Jumlah } \\
\text { Responden } \\
\text { (orang) }\end{array}$ & $\begin{array}{c}\text { Persentase } \\
\text { Responden } \\
(\%)\end{array}$ & $\begin{array}{c}\text { Total } \\
\text { Skor }\end{array}$ \\
\hline Sangat Setuju & 5 & 14 & 38,8 & 70 \\
Setuju & 4 & 19 & 52,7 & 76 \\
Ragu-Ragu & 3 & 2 & 5,5 & 6 \\
Tidak Setuju & 2 & - & - & - \\
Sangat Tidak Setuju & 1 & - & - & - \\
\hline Total & & 36 & 100 & 152
\end{tabular}

Sumber: Diolah dari Data Primer, 2016

Tabel 3 dengan Meningkatnya Pendapatan dapat juga Meningkatkan Kesejahteraan Petani

\begin{tabular}{ccccc}
\hline $\begin{array}{c}\text { Alternatif } \\
\text { Jawaban }\end{array}$ & $\begin{array}{c}\text { Alternatif } \\
\text { Skor }\end{array}$ & $\begin{array}{c}\text { Jumlah } \\
\text { Responden } \\
\text { (orang) }\end{array}$ & $\begin{array}{c}\text { Persentase } \\
\text { Responden } \\
(\%)\end{array}$ & $\begin{array}{c}\text { Total } \\
\text { Skor }\end{array}$ \\
\hline Sangat Setuju & 5 & 18 & 50 & 90 \\
Setuju & 4 & 18 & 50 & 72 \\
Ragu-Ragu & 3 & - & - & - \\
Tidak Setuju & 2 & - & - & - \\
Sangat Tidak Setuju & 1 & - & - & - \\
\hline Total & & 36 & 100 & 162 \\
\hline
\end{tabular}

Sumber: Diolah dari Data Primer, 2016

Tabel 4 Meningkatnya Kesejahteraan Petani Bisa Menyekolahkan Anak

\begin{tabular}{ccccc}
\hline $\begin{array}{c}\text { Alternatif } \\
\text { Jawaban }\end{array}$ & $\begin{array}{c}\text { Alternatif } \\
\text { Skor }\end{array}$ & $\begin{array}{c}\text { Jumlah } \\
\text { Responden } \\
\text { (orang) }\end{array}$ & $\begin{array}{c}\text { Persentase } \\
\text { Responden } \\
(\%)\end{array}$ & $\begin{array}{c}\text { Total } \\
\text { Skor }\end{array}$ \\
\hline Sangat Setuju & 5 & 16 & 44,4 & 80 \\
Setuju & 4 & 20 & 55,5 & 80 \\
Ragu-Ragu & 3 & - & - & - \\
Tidak Setuju & 2 & - & - & - \\
Sangat Tidak Setuju & 1 & - & - & - \\
\hline Total & & 36 & 100 & 160
\end{tabular}

Sumber: Diolah dari Data Primer, 2016

Tabel 5 dengan Meningkatnya Pendapatan Bapak atau Ibu bisa membuat Tabungan (saving) untuk Keluarga

\begin{tabular}{ccccc}
\hline $\begin{array}{c}\text { Alternatif } \\
\text { Jawaban }\end{array}$ & $\begin{array}{c}\text { Alternatif } \\
\text { Skor }\end{array}$ & $\begin{array}{c}\text { Jumlah } \\
\text { Responden } \\
\text { (orang) }\end{array}$ & $\begin{array}{c}\text { Persentase } \\
\text { Responden } \\
(\%)\end{array}$ & $\begin{array}{c}\text { Total } \\
\text { Skor }\end{array}$ \\
\hline Sangat Setuju & 5 & 6 & 16,6 & 30 \\
Setuju & 4 & 29 & 80,5 & 116 \\
Ragu-Ragu & 3 & 1 & 2,7 & 3 \\
Tidak Setuju & 2 & - & - & - \\
Sangat Tidak Setuju & 1 & - & - & - \\
\hline Total & & 36 & 100 & 149
\end{tabular}

Sumber: Diolah dari Data Primer, 2016 
Tabel 6 Rekapitulasi Jumlah Skor pengambilan data, Indeks persepsi, dan interpretasi pada indikator persepsi tentang keuntungan relative (Relative advance)

\begin{tabular}{llccc}
\hline No & \multicolumn{1}{c}{ Pernyataan } & $\begin{array}{c}\text { Total } \\
\text { Skor }\end{array}$ & $\begin{array}{c}\text { Indeks } \\
\text { Persepsi (\%) }\end{array}$ & Interpretasi \\
\hline 1 & $\begin{array}{l}\text { Petani mendapatkan ide baru guna untuk } \\
\text { diterapkan dalam usaha taninya }\end{array}$ & 165 & 91,6 & Sangat baik \\
2 & $\begin{array}{l}\text { Ide baru tersebut dapat meningkatkan } \\
\text { pendapatan petani }\end{array}$ & 152 & 84,4 & Sangat baik \\
3 & $\begin{array}{l}\text { Dengan meningkatnya pendapatan dapat } \\
\text { juga meningkatkan kesejahteraan petani }\end{array}$ & 162 & 90 & Sangat baik \\
\hline $\begin{array}{l}\text { Dengan meningkatnya kesejahteraan petani } \\
\text { bisa menyekolahkan anak }\end{array}$ & 160 & 88,8 & Sangat baik \\
\hline 5 & $\begin{array}{l}\text { Dengan meningkatnya pendapatan bapak } \\
\text { atau ibu bisa membuat tabungan (saving) } \\
\text { untuk keluarga }\end{array}$ & 149 & 82,7 & Sangat baik \\
\hline
\end{tabular}

Sumber: Diolah dari data primer, 2016

Tabel 7 Inovasi (ide baru) yang diberikan Penyuluh Sesuai dengan Harapan Petani

$\begin{array}{lcccc}\text { Alternatif } & \text { Alternatif } & \text { Jumlah } & \text { Persentase } & \text { Total } \\ \text { Jawaban } & \text { Skor } & \text { Responden } & \text { Responden } & \text { Skor } \\ & & \text { (orang) } & (\%) & \end{array}$

\begin{tabular}{ccccc}
\hline Sangat Setuju & 5 & 9 & 24 & 45 \\
Setuju & 4 & 22 & 61,1 & 88 \\
Ragu-Ragu & 3 & 6 & 16.6 & 18 \\
Tidak Setuju & 2 & - & - & - \\
Sangat Tidak Setuju & 1 & - & - & - \\
\hline Total & & 36 & 100 & 151 \\
\hline
\end{tabular}

Sumber: Diolah dari Data Primer, 2016

\section{Persepsi Petani terhadap Peran Penyuluh mengenai Inovasi (ide baru) yang Diberikan Penyuluh Sesuai dengan Harapan Petani}

Tabel 7 menunjukan bahwa sebagian besar responden, yaitu $22(61,1)$ setuju, serta terdapat 9 atau (24\%) yang sangat setuju dan yang menjawab Ragu-ragu terdapat $6(16,6 \%)$ yang tidak setuju bahwa inovasi yang diberikan penyuluh pertanian sesuai dengan harapan petani. Dalam indikator ini, total skor persepsi petani sebesar 151/180 x 100\% = 83,3\%, sehingga interpretasi nilainya tergolong sangat baik. Hal yang melatarbelakangi persepsi petani sangat baik terhadap peran penyuluh dalam hal ini inovasi yang diberikan penyuluh pertanian sesuai dengan harapan petani adalah karna para penyuluh memberikan inovasi misalnya memberi saran pada para petani cara pemilihan bibit yang sesuai atau varietas unggul pemberian pupuk dengan dosis yang sesuai dengan kebutuhan tanaman dan cara pemeliharaan tanaman lainnya.

\section{Persepsi Petani terhadap Peran Penyuluh berdasarkan Kecocokannya dengan Adat Istiadat dan Kebiasaan Petani}

Tabel 8 menunjukan bahwa sebagian besar responden, yaitu 17 (42,2\%) setuju, serta $10(27,7 \%)$ responden sangat setuju, ada juga 8 $(22,2 \%)$ responden yang menjawab ragu-ragu, dan terdapat 1 atau $(2,7 \%)$ yang tidak setuju bahwa inovasi yang diberikan penyuluh dapat disesuaikan dengan adat istiadat yang ada pada petani. Dalam indikator ini, total skor persepsi petani sebesar $144 / 180 \times 100 \%=80 \%$, sehingga interpretasi nilainya tergolong baik. Menurut wawancara saya dengan petani hal yang melatarbelakangi persepsi petani terhadap peran penyuluh hanya baik dalam hal ini inovasi yang diberikan penyuluh dapat disesuaikan dengan 
adat istiadat yang ada pada petani adalah karna dalam memberikan inovasi atau ide baru, misalnya penyuluh menyarankan menanam tanaman misalnya tomat para penyuluh tidak memperhitungkan keadaan cuaca, bulan dan lain-lain, sedangkan para petani masi menganut kepercayaan atau adat istiadat cara melihat cuaca, bulan untuk menanam suatu jenis tanaman sesuai dengan cuaca dan bulan.

\section{Persepsi Petani terhadap Peran Penyuluh mengenai Inovasi yang Diberikan Penyuluh dapat Memenuhi Harapan Petani}

Tabel 9 menunjukan bahwa sebagian besar responden, yaitu $22(61,1 \%)$ setuju, serta terdapat $9(25 \%)$ responden yang sangat setuju, dan ada juga $5(13,8 \%)$ yang menjawab raguragu bahwa inovasi yang diberikan penyuluh dapat memenuhi harapan petani. Dalam indikator ini, total skor persepsi petani sebesar $148 / 180 \times 100 \%=82,2 \%$, sehingga interpretasi nilainya tergolong baik. Hal yang melatarbelakangi persepsi petani sangat baik terhadap peran penyuluh dalam hal ini inovasi yang diberikan penyuluh dapat memenuhi harapan petani adalah menurut wawancara saya dengan para petani sebagian besar mereka menjawab bahwa dengan adanya inovasi atau ide baru dari penyuluh pertanian harapan mereka yaitu peningkatan produksi hasil-hasil pertanian bisa tercapai.

\section{Persepsi Petani terhadap Peran Penyuluh mengenai Harapan Petani Tersebut Apakah bisa Membangun Tempat Tinggal (Rumah)}

Tabel 10 menunjukan bahwa sebagian besar responden, yaitu $25(69,4 \%)$ setuju, serta $6(16,6 \%)$ responden yang sangat setuju, dan ada juga $5(13,8 \%)$ responden yang ragu-ragu mengenai harapan petani tersebut apakah bisa membangun tempat tinggal (rumah). Dalam indikator ini, total skor persepsi petani sebesar $145 / 180 \times 100 \%=80,5 \%$, sehingga interpretasi nilainya tergolong baik. Hal yang melatarbelakangi persepsi petani baik terhadap peran penyuluh dalam hal ini harapan petani bisa membangun tempat tinggal (rumah), adalah menurut wawancara saya dengan petani sebagian besar mereka menjawab memang saya membuat rumah ini hanya dengan mengandalkan penjualan hasil-hasil pertanian.
Persepsi Petani terhadap Peran Penyuluh mengenai Tempat Tinggal (Rumah) tersebut Sesuai dengan Ekspektasi (harapan) Petani

Tabel 11 menunjukan bahwa sebagian besar responden, yaitu $24(66,6 \%)$ setuju, serta terdapat $6(16,6 \%)$ responden yang sangat setuju dan terdapat juga $8(22,2 \%)$ yang raguragu mengenai tempat tinggal tersebut sesuai dengan ekspektasi (harapan) petani. Dalam indikator ini, total skor persepsi petani sebesar $150 / 180 \times 100 \%=83,3 \%$, sehingga interpretasi nilainya tergolong sangat baik. Hal yang melatarbelakangi persepsi petani sangat baik terhadap peran penyuluh dalam hal ini tempat tinggal tersebut sesuai dengan harapan petani adalah sebagian besar petani berpendapat bahwa rumah ini memang sesuai harapan saya karna secara tidak langsung saya yang membuatnya.

\section{Rekapitulasi Persepsi Petani Terhadap Tingkat Kesesuaian (Compatibility)}

Tabel 12 menunjukan 5 pernyataan tentang persepsi petani terhadap tingkat kesesuaian (compatibility) Pernyataan dengan jumlah indeks tertiggi adalah pernyataan 1 yaitu 83,8 selanjutnta pernytaan 5 yaitu 83,3 selanjutnya pernyataan 3 yaitu 82,2 selanjutnya pernyataan 4 yaitu 80,5 dan pernyataan 2 yaitu 80.

\section{Persepsi Petani terhadap Tingkat Kerumitan (complexity)}

Persepsi petani mengenai tingkat kerumitan dalam hal ini penggunaan peran penyuluh dalam memberikan inovasi (ide baru), apakah dalam prakteknya inovasi penyuluh sulit dilakukan (cara penanaman dan pemeliharaan tanaman) oleh petani dan penggunaan mesinmesin pertanian (pembajak sawah, rontok dan alat-alat mesin pertanian lainnya) yang bisa mempercepat pekerjaan petani.

\section{Persepsi Petani terhadap Peran Penyuluh mengenai dalam Prakteknya Inovasi Penyuluh Lebih Sulit Dilakukan}

Tabel 13 menunjukan bahwa sebagian besar responden, yaitu $11(30,5 \%)$ setuju, serta $15(41,6 \%)$ responden yang tidak setuju, ada juga $9(25 \%)$ responden yang ragu-ragu dan ada juga 1 atau $(2,7 \%)$ yang sangat setuju bahwa dalam prakteknya inovasi penyuluh lebih sulit dilakukan. Dalam indikator ini, total skor 
persepsi petani sebesar 106/180 x 100\%= $58,8 \%$, sehingga interpretasi nilainya tergolong kurang baik. Hal yang melatarbelakangi persepsi petani kurang baik mengenai dalam prakteknya inovasi penyuluh lebih sulit dilakukan karna menurut wawancara saya dengan petani sebagian besar mereka menjawab inovasi penyuluh mudah dilakukan.

\section{Persepsi Petani terhadap Peran Penyuluh mengenai Petani Sulit Memahami Inovasi Penyuluh}

Tabel 14 menunjukan bahwa sebagian besar responden, yaitu $23(63,8)$ setuju, serta $6(16,6)$ responden yang sangat setuju, serta masingmasing $3(8,3 \%)$ respondeng yang merasa raguragu dan tidak setuju, dan hanya terdapat $1(2,7)$ responden yang sangat tidak setuju bahwa petani sulit memahami inovasi penyuluh. Dalam indikator ini, total skor persepsi petani sebesar $138 / 180 \times 100 \%=76,6 \%$, sehingga interpretasi nilainya tergolong baik. Hal yang melatarbelakangi persepsi petani hanya baik terhadap penyuluh adalah menurut wawancara saya dengan petani sebagian besar mereka menjawab bahwa tidak semua inovasi penyuluh mudah dilakukan oleh petani, karna tidak sesuai dengan adat istiadat yang dianut masyarakat petani.

\section{Persepsi Petani terhadap Peran Penyuluh mengenai Inovasi Penyuluh (mesin-mesin) Lebih Mudah Dibanding dengan caraPenggunaan alat-alat Tradisional}

Tabel 15 menunjukan bahwa sebagian besar responden, yaitu $19(52,7 \%)$ setuju, serta terdapat $14(38,8 \%)$ responden yang sangat setuju, dan ada juga $2(5,5 \%)$ yang merasa ragu-ragu bahwa inovasi penyuluh (mesin-mesin) lebih mudah dibanding dengan cara penggunaan alatalat tradisional. Dalam indikator ini, total skor persepsi petani sebesar $152 / 180 \times 100 \%=84,4 \%$, sehingga interpretasi nilainya tergolong sangat baik. Menurut wawancara saya dengan petani dilapangan hal yang melatarbelakangi persepsi petani sangat baik terhadap peran penyuluh dalam hal ini inovasi penyuluh (mesin-mesin) lebih mudah dibanding dengan cara penggunaan alatalat tradisional adalah sebagian besar mereka menjawab bahwa dengan penggunaan alat mesin pertanian bisa lebih mudah dalam pengolahan tanah, perontok padi dan kegiatan pertanian lainnya yang bisa dengan mudah dilakukan dengan penggunaan alat mesin pertanian.

Tabel 8 Kecocokannya dengan Adat Istiadat dan Kebiasaan Petani

\begin{tabular}{ccccc}
\hline $\begin{array}{c}\text { Alternatif } \\
\text { Jawaban }\end{array}$ & $\begin{array}{c}\text { Alternatif } \\
\text { Skor }\end{array}$ & $\begin{array}{c}\text { Jumlah } \\
\text { Responden } \\
\text { (orang) }\end{array}$ & $\begin{array}{c}\text { Persentase } \\
\text { Responden } \\
(\%)\end{array}$ & $\begin{array}{c}\text { Total } \\
\text { Skor }\end{array}$ \\
\hline Sangat Setuju & 5 & 10 & 27,7 & 50 \\
Setuju & 4 & 17 & 42,2 & 68 \\
Ragu-Ragu & 3 & 8 & 22,2 & 24 \\
Tidak Setuju & 2 & 1 & 2,7 & 2 \\
Sangat Tidak Setuju & 1 & - & - & - \\
\hline Total & & 36 & 100 & 144
\end{tabular}

Sumber: Diolah dari Data Primer, 2016

Tabel 9 Inovasi yang Diberikan Penyuluh dapat Memenuhi Harapan Petani

\begin{tabular}{ccccc}
\hline $\begin{array}{c}\text { Alternatif } \\
\text { Jawaban }\end{array}$ & $\begin{array}{c}\text { Alternatif } \\
\text { Skor }\end{array}$ & $\begin{array}{c}\text { Jumlah } \\
\text { Responden } \\
\text { (orang) }\end{array}$ & $\begin{array}{c}\text { Persentase } \\
\text { Responden } \\
(\%)\end{array}$ & $\begin{array}{c}\text { Total } \\
\text { Skor }\end{array}$ \\
\hline Sangat Setuju & 5 & 9 & 25 & 45 \\
Setuju & 4 & 22 & 61,1 & 88 \\
Ragu-Ragu & 3 & 5 & 13,8 & 15 \\
Tidak Setuju & 2 & - & - & - \\
Sangat Tidak Setuju & 1 & - & - & - \\
\hline Total & & 36 & 100 & 148 \\
\hline
\end{tabular}

Sumber: Diolah dari Data Primer, 2016 
Tabel 10. Harapan Petani Tersebut Apakah bisa Membangun Tempat Tinggal (Rumah)

\begin{tabular}{ccccc}
\hline $\begin{array}{c}\text { Alternatif } \\
\text { Jawaban }\end{array}$ & $\begin{array}{c}\text { Alternatif } \\
\text { Skor }\end{array}$ & $\begin{array}{c}\text { Jumlah } \\
\text { Responden } \\
\text { (orang) }\end{array}$ & $\begin{array}{c}\text { Persentase } \\
\text { Responden } \\
(\%)\end{array}$ & $\begin{array}{c}\text { Total } \\
\text { Skor }\end{array}$ \\
\hline Sangat Setuju & 5 & 6 & 16,6 & 30 \\
Setuju & 4 & 25 & 69.4 & 100 \\
Ragu-Ragu & 3 & 5 & 13,8 & 15 \\
Tidak Setuju & 2 & - & - & - \\
Sangat Tidak Setuju & 1 & - & - & - \\
\hline Total & & 36 & 100 & 145 \\
\hline
\end{tabular}

Sumber: Diolah dari Data Primer, 2016

Tabel 11 Tempat Tinggal (Rumah) tersebut Sesuai dengan Ekspektasi (harapan) Petani

\begin{tabular}{ccccc}
\hline $\begin{array}{c}\text { Alternatif } \\
\text { Jawaban }\end{array}$ & $\begin{array}{c}\text { Alternatif } \\
\text { Skor }\end{array}$ & $\begin{array}{c}\text { Jumlah } \\
\text { Responden } \\
\text { (orang) }\end{array}$ & $\begin{array}{c}\text { Persentase } \\
\text { Responden } \\
(\%)\end{array}$ & $\begin{array}{c}\text { Total } \\
\text { Skor }\end{array}$ \\
\hline Sangat Setuju & 5 & 6 & 16,6 & 30 \\
Setuju & 4 & 24 & 66,6 & 96 \\
Ragu-Ragu & 3 & 8 & 22,2 & 24 \\
Tidak Setuju & 2 & - & - & - \\
Sangat Tidak Setuju & 1 & - & - & 100 \\
\hline Total & & 36 & 100 & 150 \\
\hline
\end{tabular}

\section{Sumber: Diolah dari Data Primer, 2016}

Tabel 12. Rekapitulasi Jumlah Skor pengambilan data, Indeks persepsi, dan interpretasi pada indikator persepsi tentang tingkat kesesuaian (compatibility)

\begin{tabular}{|c|c|c|c|c|}
\hline No & Pernyataan & $\begin{array}{l}\text { Total } \\
\text { Skor }\end{array}$ & $\begin{array}{l}\text { Indeks Persepsi } \\
(\%)\end{array}$ & Interpretasi \\
\hline 1 & $\begin{array}{l}\text { Inovasi (ide baru) yang di berikan } \\
\text { penyuluh sesuai dengan harapan petani }\end{array}$ & 151 & 83,8 & Sangat Baik \\
\hline 2 & $\begin{array}{l}\text { Inovasi yang diberikan penyuluh dapat } \\
\text { disesuaikan dengan adat kebiasaan yang ada pada } \\
\text { petani }\end{array}$ & 144 & 80 & Baik \\
\hline 3 & $\begin{array}{l}\text { Inovasi yang diberikan penyuluh dapat memenuhi } \\
\text { harapan petani }\end{array}$ & 148 & 82,2 & Sangat Baik \\
\hline 4 & $\begin{array}{l}\text { Harapan petani tersebut apakah bisa membangun } \\
\text { tempat tinggal (rumah) }\end{array}$ & 145 & 80,5 & Baik \\
\hline 5 & $\begin{array}{l}\text { Tempat tinggal tersebut sesuai dengan ekspektasi } \\
\text { petani (harapan petani) }\end{array}$ & 150 & 83,3 & Sangat Baik \\
\hline
\end{tabular}

Sumber: Diolah dari data primer, 2016

Tabel 13 dalam Prakteknya Inovasi Penyuluh Lebih Sulit Dilakukan

\begin{tabular}{ccccc}
\hline $\begin{array}{c}\text { Alternatif } \\
\text { Jawaban }\end{array}$ & $\begin{array}{c}\text { Alternatif } \\
\text { Skor }\end{array}$ & $\begin{array}{c}\text { Jumlah } \\
\text { Responden } \\
\text { (orang) }\end{array}$ & $\begin{array}{c}\text { Persentase } \\
\text { Responden } \\
(\%)\end{array}$ & $\begin{array}{c}\text { Total } \\
\text { Skor }\end{array}$ \\
\hline Sangat Setuju & 5 & 1 & 2,7 & 5 \\
Setuju & 4 & 11 & 30,5 & 44 \\
Ragu-Ragu & 3 & 9 & 25 & 27 \\
Tidak Setuju & 2 & 15 & 41,6 & 30 \\
Sangat Tidak Setuju & 1 & - & - & - \\
\hline Total & & 36 & 100 & 106 \\
\hline
\end{tabular}

Sumber: Diolah dari Data Primer, 2016 
Tabel 14 Petani Sulit Memahami Inovasi Penyuluh

\begin{tabular}{ccccc}
\hline $\begin{array}{c}\text { Alternatif } \\
\text { Jawaban }\end{array}$ & $\begin{array}{c}\text { Alternatif } \\
\text { Skor }\end{array}$ & $\begin{array}{c}\text { Jumlah } \\
\text { Responden } \\
(\text { orang) }\end{array}$ & $\begin{array}{c}\text { Persentase } \\
\text { Responden } \\
(\%)\end{array}$ & $\begin{array}{c}\text { Total } \\
\text { Skor }\end{array}$ \\
\hline Sangat Setuju & 5 & 6 & 16,6 & 30 \\
Setuju & 4 & 23 & 63,8 & 92 \\
Ragu-Ragu & 3 & 3 & 8,3 & 9 \\
Tidak Setuju & 2 & 3 & 8,3 & 6 \\
Sangat Tidak Setuju & 1 & 1 & 2,77 & 1 \\
\hline Total & & 36 & 100 & 138 \\
\hline Sumber: Diolah dari Data Primer, 2016 & &
\end{tabular}

Tabel 15 Inovasi Penyuluh (mesin-mesin) Lebih Mudah Dibanding dengan cara Penggunaan alat-alat Tradisional

\begin{tabular}{ccccc}
\hline $\begin{array}{c}\text { Alternatif } \\
\text { Jawaban }\end{array}$ & $\begin{array}{c}\text { Alternatif } \\
\text { Skor }\end{array}$ & $\begin{array}{c}\text { Jumlah } \\
\text { Responden } \\
\text { (orang) }\end{array}$ & $\begin{array}{c}\text { Persentase } \\
\text { Responden } \\
(\%)\end{array}$ & $\begin{array}{c}\text { Total } \\
\text { Skor }\end{array}$ \\
\hline Sangat Setuju & 5 & 14 & 38,8 & 70 \\
Setuju & 4 & 19 & 52,7 & 76 \\
Ragu-Ragu & 3 & 2 & 5,5 & 6 \\
Tidak Setuju & 2 & - & - & - \\
Sangat Tidak Setuju & 1 & - & - & - \\
\hline Total & & 36 & 100 & 152 \\
\hline
\end{tabular}

Sumber: Diolah dari Data Primer, 2016

Tabel 16 Penggunaan mesin pertanian bisa mempercepat pekerjaan petani

\begin{tabular}{ccccc}
\hline $\begin{array}{c}\text { Alternatif } \\
\text { Jawaban }\end{array}$ & $\begin{array}{c}\text { Alternatif } \\
\text { Skor }\end{array}$ & $\begin{array}{c}\text { Jumlah } \\
\text { Responden } \\
\text { (orang) }\end{array}$ & $\begin{array}{c}\text { Persentase } \\
\text { Responden } \\
(\%)\end{array}$ & $\begin{array}{c}\text { Total } \\
\text { Skor }\end{array}$ \\
\hline Sangat Setuju & 5 & 17 & 47,2 & 85 \\
Setuju & 4 & 19 & 52,7 & 76 \\
Ragu-Ragu & 3 & - & - & - \\
Tidak Setuju & 2 & - & - & - \\
Sangat Tidak Setuju & 1 & - & - & - \\
\hline Total & & 36 & 100 & 161 \\
\hline
\end{tabular}

Sumber: Diolah dari Data Primer, 2016

Tabel 17 penggunaan mesin pertanian bisa menghemat waktu dan biaya

\begin{tabular}{ccccc}
\hline $\begin{array}{l}\text { Alternatif } \\
\text { Jawaban }\end{array}$ & $\begin{array}{c}\text { Alternatif } \\
\text { Skor }\end{array}$ & $\begin{array}{c}\text { Jumlah } \\
\text { Responden } \\
\text { (orang) }\end{array}$ & $\begin{array}{c}\text { Persentase } \\
\text { Responden } \\
(\%)\end{array}$ & $\begin{array}{c}\text { Total } \\
\text { Skor }\end{array}$ \\
\hline Sangat Setuju & 5 & 17 & 47,2 & 85 \\
Setuju & 4 & 14 & 38,8 & 56 \\
Ragu-Ragu & 3 & 5 & 13,8 & 15 \\
Tidak Setuju & 2 & - & - & - \\
Sangat Tidak Setuju & 1 & - & - & - \\
\hline Total & & 36 & 100 & 156 \\
\hline
\end{tabular}

Sumber: Diolah dari Data Primer, 2016 


\section{Persepsi Petani terhadap Peran Penyuluh mengenai Penggunaan Mesin Pertanian Bisa Mempercepat Pekerjaan Petani}

Tabel 16 menunjukan bahwa sebagian besar responden, yaitu $19(52,7 \%)$ setuju, serta terdapat $17(47,2 \%)$ responden yang sangat setuju bahwa penggunaan mesin pertanian bisa mempercepat pekerjaan petani. Dalam indikator ini, total skor persepsi petani sebesar 161/180 x $100 \%=89,4 \%$, sehingga interpretasi nilainya tergolong sangat baik. Hal yang melatarbelakangi persepsi petani sangat baik terhadap peran penyuluh dalam hal ini penggunaan mesin pertanian bisa mempercepat pekerjaan petani adalah munurut wawancara saya dengan petani sebagian besar mereka menjawab bahwa dengan penggunaan alat mesin pertanian bisa mempercepat pekerjaan petani misalnya dalam pengolahan tanah, perontok padi dan mesin penggilingan padi.

\section{Persepsi Petani terhadap Peran Penyuluh mengenai Penggunaan Mesin Pertanian Bisa Menghemat Waktu dan Biaya \\ Tabel 17 menunjukan bahwa sebagian} besar responden, yaitu $17(47,2 \%)$ sangat setuju, serta $14(38,8 \%)$ yang setuju, dan ada juga 5 $(13,8 \%)$ responden yang ragu-ragu bahwa dengan penggunaan mesin pertanian bisa menghemat waktu dan biaya. Dalam indikator ini, total skor persepsi petani sebesar $156 / 180 \times 100 \%=86,6 \%$, sehingga interpretasi nilainya tergolong sangat baik. Menurut wawancara saya dengan petani hal yang melatarbelakangi persepsi petani sangat baik terhadap peran penyuluh dalam hal ini penggunaan alat mesin pertanian bisa menghemat waktu dan biaya adalah sebagian besar petani mengatakan bahwa memang dengan penggunaan alat mesin pertanian petani bisa menghemat waktu dan biaya sehingga selain cepat dalam pekerjaan biayanyapun murah atau terjangkau.

\section{Rekapitulasi Persepsi Petani Terhadap Tingkat Kerumitan (Complexity)}

Tabel 16 Menunjukan 5 pernyataan tentang persepsi petani terhadap tingkat kerumitan (complexity) Pernyataan dengan jumlah indeks tertiggi adalah pernyataan 4 yaitu 89,4 selanjutnta pernytaan 5 yaitu 86,6 selanjutnya pernyataan 3 yaitu 84,4 selanjutnya pernyataan 2 yaitu 76,6 dan pernyataan 1 yaitu 58,8 .

\section{Persepsi Petani terhadap Tingkat Kemudahan untuk Dicoba (triability)}

Persepsi petani mengenai tingkat kemudahan peran (inovasi) penyuluh untuk dicoba mencakup kemudahan untuk menerapkan inovasi penyuluh dalam usahatani petani.

\section{Persepsi Petani terhadap Peran Penyuluh mengenai Petani Mau Mencoba Inovasi Penyuluh Pertanian}

Tabel 18 menunjukan bahwa sebagian besar responden, yaitu $28(77,7 \%)$ setuju, serta 6 $(16,6 \%)$ responden yang sangat setuju, dan terdapat $2(5,5 \%)$ responden yang masih merasa ragu-ragu bahwa petani mau mencoba inovasi penyuluh pertanian. Dalam indikator ini, total skor persepsi petani sebesar 148/180 × $100 \%=$ $82,2 \%$, sehingga interpretasi nilainya tergolong sangat baik. Hal yang melatarbelakangi persepsi petani sangat baik terhadap peran penyuluh dalam hal ini petani mau mencoba inovasi penyuluh pertanian adalah menurut wawancara saya dengan para petani kenapa mau mencoba inovasi penyuluh dan sebagian besar dari petani menjawab karena penyuluh pertanian memberikan inovasi yang mudah sehingga petani bisa menerapkan atau mengaplikasikannya dalam usaha taninya tanpa kesulitan.

\section{Persepsi Petani terhadap Peran Penyuluh mengenai Petani Bisa dengan Mudah Mencoba Inovasi Penyuluh Pertanian}

Tabel 19 menunjukan bahwa sebagian besar responden, yaitu $28(77,7 \%)$ setuju, serta terdapat masing-masing $4(11,1 \%)$ responden sangat setuju dan ragu-ragu bahwa petani bisa dengan mudah mencoba inovasi penyuluh pertanian. Dalam indikator ini, total skor persepsi petani sebesar 144/180 x 100\% $=80 \%$, sehingga interpretasi nilainya tergolong baik. Hal yang melatarbelakangi persepsi petani baik terhadap peran penyuluh dalam hal ini petani bisa dengan mudah mencoba inovasi penyuluh adalah karna inovasi yang di berikan penyuluh tidak jauh beda dengan cara bertani para petani sehingga inovasi penyuluh ini semakin melengkapi pengetahuan petani tentang cara bertani yang baik sehingga bisa memenuhi harapan petani yaitu peningkatan produksi atau peningkatan pendapatan keluarga petani. 


\section{Persepsi Petani terhadap Peran Penyuluh mengenai dalam Prakteknya Inovasi Penyuluh Muda Dilakukan oleh Penyuluh}

Tabel 20 menunjukan bahwa sebagian besar responden, yaitu $21(58,3 \%)$ setuju, serta $8(22,2 \%)$ sangat setuju, dan terdapat juga $7(19,4 \%)$ yang merasa ragu-ragu bahwa dalam prakteknya inovasi penyuluh mudah dilakukan oleh petani. Dalam indikator ini, total skor persepsi petani sebesar $145 / 180 \times 100 \%=80,5 \%$, sehingga interpretasi nilainya tergolong baik. Hal yang melatarbelakangi persepsi petani baik terhadap peran penyuluh dalam hal ini dalam prakteknya inovasi penyuluh mudah di lakukan oleh petani adalah menurut wawancara saya dengan petani dilapangan mereka menjawab karna penyuluh memberikan inovasi yang mudah di praktekkan atau mudah di terapkan dalam usaha tani para petani misalnya cara penanaman yang baik dan benar, pemeliharaan dan cara penanganan pasca panen.

\section{Persepsi Petani terhadap Peran Penyuluh mengenai Tingkat Kemudahan Inovasi Penyuluh Mudah Dicoba oleh Petani}

Tabel 21 menunjukan bahwa sebagian besar responden, yaitu $24(66,6 \%)$ setuju, serta $6(16,6 \%)$ sangat setuju serta $5(13,8 \%)$ responden masih merasa ragu-ragu dan $2(2,7 \%)$ responden lainnya tidak setuju bahwa tingkat kemudahan inovasi penyuluh mudah dilakukan oleh petani. Dalam indikator ini, total skor persepsi petani sebesar $143 / 180 \times 100 \%=79,4 \%$, sehingga interpretasi nilainya tergolong baik. Hal yang melatarbelakangi persepsi petani baik terhadap peran penyuluh dalam hal ini tingkat kemudahan inovasi penyuluh mudah dilakukan oleh petani adalah menurut para petani penyuluh memberikan inovasi yang mudah dilakukan atau diterapkan dalam usaha tani mereka sehingga petani tidak menemukan kesulitan untuk mencoba inovasi penyuluh pertanian.

\section{Persepsi Petani terhadap Peran Penyuluh mengenai Dengan Kemudahan Inovasi Penyuluh Pertanian Bisa Membuat Petani Menggunakan Inovasi (mesin pertanian) secara Terus-menerus}

Tabel 22 menunjukan bahwa sebagian besar responden, yaitu $12(33,3 \%)$ setuju, serta 8 $(22,2 \%)$ sangat setuju, $9(25 \%)$ responden masih merasa ragu-ragu dan $7(19,4 \%)$ yang tidak setuju bahwa dengan kemudahan inovasi penyuluh pertanian bisa membuat petani menggunakan inovasi (mesin pertanian) secara terus-menerus. Dalam indikator ini, total skor persepsi petani sebesar $129 / 180 \times 100 \%=71,6 \%$, sehingga interpretasi nilainya tergolong baik. Hal yang melatarbelakangi persepsi petani hanya baik terhadap peran penyuluh dalam hal ini dengan kemudahan inovasi penyuluh pertanian bisa membuat petani menggunakan inovasi (mesin pertanian) secara terus-menerus adalah menurut wawancara saya dengan petani walaupun penggunaan alat mesin pertanian bisa mempercepat pekerjaan petani tapi para petani tidak bisa terus-menerus menggunakan alat mesin pertanian karna tidak selalu alat mesin pertanian tersedia, untuk itu para petani menggunakan alat tradisional kalau alat mesin pertanian tidak tersedia saat dibutuhkan misalnya dalam pengolahan tanah untuk padi sawah para petani menggunakan bajak yang ditarik oleh hewan.

\section{Rekapitulasi Persepsi Petani Terhadap Tingkat Kemudahan untuk Dicoba (Triability)}

Tabel 23 Menunjukan 5 pernyataan tentang persepsi petani terhadap tingkat kemudahan untuk dicoba (triability) Pernyataan dengan jumlah indeks tertiggi adalah pernyataan 1 yaitu 82,2 selanjutnta pernytaan 3 yaitu 80,5 selanjutnya pernyataan 2 yaitu 80 selanjutnya pernyataan 4 yaitu 79,4 dan pernyataan 5 yaitu 71,6

\section{Persepsi Petani terhadap Tingkat Kemudahan untuk Dilihat Hasilnya (Observability)}

Persepsi petani mengenai tingkat kemudahan untuk melihat hasil penggunaan inovasi penyuluh dan hasilnya dapat mudah diamati dalam hal ini peningkatan pendapatan petani petani secara nyata, serta pendapatan tersebut lebih besar dari sebelum petani menggunakan inovasi penyuluh pertanian.

\section{Persepsi Petani terhadap Peran Penyuluh mengenai Tingkat Kemudahan Inovasi Penyuluh Dapat dengan Mudah Dipraktekkan}

Tabel 24 menunjukan bahwa sebagian besar responden, yaitu $20(55,5 \%)$ setuju, diikuti 10 $(27,7 \%)$ responden sangat setuju, dan $6(16,6 \%)$ responden yang masih ragu-ragu bahwa tingkat kemudahan inovasi penyuluh dapat dengan mudah dipraktekkan. Dalam indikator ini, total skor persepsi petani sebesar 148/180 x 100\% $=82,2 \%$, sehingga interpretasi nilainya tergolong sangat baik. Hal yang melatarbelakangi persepsi petani sangat baik terhadap peran penyuluh dalam hal ini tingkat kemudahan inovasi penyuluh dapat dengan mudah dipraktekkan adalah menurut wawancara saya dengan petani di lapangan sebagian besar mereka mengatakan karena para penyuluh memberikan inovasi yang mudah dimengerti sehingga petani bisa dengan mudah menerapkan saran atau ide baru dari penyuluh ke usaha taninya. 
Tabel 18 Rekapitulasi Jumlah Skor pengambilan data, Indeks persepsi, dan interpretasi pada indikator persepsi tentang tingkat kerumitan (complexity)

\begin{tabular}{llccc}
\hline No & \multicolumn{1}{c}{ Pernyataan } & $\begin{array}{c}\text { Total } \\
\text { Skor }\end{array}$ & $\begin{array}{c}\text { Indeks } \\
\text { Persepsi (\%) }\end{array}$ & Interpretasi \\
\hline 1 & Petani sulit memahami inovasi penyuluh \\
2 & $\begin{array}{l}\text { Dalam prakteknya inovasi penyuluh lebih } \\
\text { sulit dilakukan oleh petani }\end{array}$ & 141 & 58,8 & $\begin{array}{l}\text { Kurang Baik } \\
\text { Baik }\end{array}$ \\
3 & $\begin{array}{l}\text { Inovasi penyuluh (mesin-mesin) lebih } \\
\text { mudah dibanding dengan cara penggunaan } \\
\text { alat-alat tradisional }\end{array}$ & 148 & 84,4 & Sangat Baik \\
4 & $\begin{array}{l}\text { Penggunaan mesin pertanian bisa } \\
\text { mempercepat pekerjaan petani }\end{array}$ & 145 & 89,4 & Sangat Baik \\
\hline 5 & $\begin{array}{l}\text { Dengan menggunakan mesin pertanian } \\
\text { petani bisa menghemat waktu dan biaya }\end{array}$ & 150 & 86,6 & Sangat Baik \\
\hline
\end{tabular}

Sumber: Diolah dari data primer, 2016

Tabel 19 Petani Mau Mencoba Inovasi Penyuluh Pertanian

\begin{tabular}{ccccc}
\hline $\begin{array}{l}\text { Alternatif } \\
\text { Jawaban }\end{array}$ & $\begin{array}{c}\text { Alternatif } \\
\text { Skor }\end{array}$ & $\begin{array}{c}\text { Jumlah } \\
\text { Responden } \\
\text { (orang) }\end{array}$ & $\begin{array}{c}\text { Persentase } \\
\text { Responden } \\
(\%)\end{array}$ & $\begin{array}{c}\text { Total } \\
\text { Skor }\end{array}$ \\
\hline Sangat Setuju & 5 & 6 & 16,6 & 30 \\
Setuju & 4 & 28 & 77,7 & 112 \\
Ragu-Ragu & 3 & 2 & 5,5 & 6 \\
Tidak Setuju & 2 & - & - & - \\
Sangat Tidak Setuju & 1 & - & - & - \\
\hline Total & & 36 & 100 & 148 \\
\hline
\end{tabular}

Sumber: Diolah dari Data Primer, 2016

Tabel 20 Petani Bisa dengan Mudah Mencoba Inovasi Penyuluh Pertanian

\begin{tabular}{ccccc}
\hline $\begin{array}{c}\text { Alternatif } \\
\text { Jawaban }\end{array}$ & $\begin{array}{c}\text { Alternatif } \\
\text { Skor }\end{array}$ & $\begin{array}{c}\text { Jumlah } \\
\text { Responden } \\
\text { (orang) }\end{array}$ & $\begin{array}{c}\text { Persentase } \\
\text { Responden } \\
(\%)\end{array}$ & $\begin{array}{c}\text { Total } \\
\text { Skor }\end{array}$ \\
\hline Sangat Setuju & 5 & 4 & 11,1 & 20 \\
Setuju & 4 & 28 & 77,7 & 112 \\
Ragu-Ragu & 3 & 4 & 11,1 & 12 \\
Tidak Setuju & 2 & - & - & - \\
Sangat Tidak Setuju & 1 & - & - & - \\
\hline Total & & 36 & 100 & 144 \\
\hline
\end{tabular}

Sumber: Diolah dari Data Primer, 2016

Tabel 21 dalam Prakteknya Inovasi Penyuluh Muda Dilakukan oleh Penyuluh

\begin{tabular}{ccccc}
\hline $\begin{array}{c}\text { Alternatif } \\
\text { Jawaban }\end{array}$ & $\begin{array}{c}\text { Alternatif } \\
\text { Skor }\end{array}$ & $\begin{array}{c}\text { Jumlah } \\
\text { Responden } \\
\text { (orang) }\end{array}$ & $\begin{array}{c}\text { Persentase } \\
\text { Responden } \\
(\%)\end{array}$ & $\begin{array}{c}\text { Total } \\
\text { Skor }\end{array}$ \\
\hline Sangat Setuju & 5 & 8 & 22,2 & 40 \\
Setuju & 4 & 21 & 58,3 & 84 \\
Ragu-Ragu & 3 & 7 & 19,4 & 21 \\
Tidak Setuju & 2 & - & - & - \\
Sangat Tidak Setuju & 1 & - & - & - \\
\hline Total & & 36 & 100 & 145 \\
\hline
\end{tabular}

Sumber: Diolah dari Data Primer, 2016 
Tabel 22 Kemudahan Inovasi Penyuluh Mudah Dicoba oleh Petani

\begin{tabular}{ccccc}
\hline $\begin{array}{c}\text { Alternatif } \\
\text { Jawaban }\end{array}$ & $\begin{array}{c}\text { Alternatif } \\
\text { Skor }\end{array}$ & $\begin{array}{c}\text { Jumlah } \\
\text { Responden } \\
\text { (orang) }\end{array}$ & $\begin{array}{c}\text { Persentase } \\
\text { Responden } \\
(\%)\end{array}$ & $\begin{array}{c}\text { Total } \\
\text { Skor }\end{array}$ \\
\hline Sangat Setuju & 5 & 6 & 16,6 & 30 \\
Setuju & 4 & 24 & 66,6 & 96 \\
Ragu-Ragu & 3 & 5 & 13,8 & 15 \\
Tidak Setuju & 2 & 1 & 2,7 & 2 \\
Sangat Tidak Setuju & 1 & - & - & - \\
\hline Total & & 36 & 100 & 143 \\
\hline
\end{tabular}

Sumber: Diolah dari Data Primer, 2016

Tabel 23 Dengan Kemudahan Inovasi Penyuluh Pertanian Bisa Membuat Petani Menggunakan Inovasi (mesin pertanian) secara Terus-menerus

\begin{tabular}{ccccc}
\hline $\begin{array}{c}\text { Alternatif } \\
\text { Jawaban }\end{array}$ & $\begin{array}{c}\text { Alternatif } \\
\text { Skor }\end{array}$ & $\begin{array}{c}\text { Jumlah } \\
\text { Responden } \\
\text { (orang) }\end{array}$ & $\begin{array}{c}\text { Persentase } \\
\text { Responden } \\
(\%)\end{array}$ & $\begin{array}{c}\text { Total } \\
\text { Skor }\end{array}$ \\
\hline Sangat Setuju & 5 & 8 & 22,2 & 40 \\
Setuju & 4 & 12 & 33,3 & 48 \\
Ragu-Ragu & 3 & 9 & 25 & 27 \\
Tidak Setuju & 2 & 7 & 19,4 & 14 \\
Sangat Tidak Setuju & 1 & - & - & - \\
\hline Total & & 36 & 100 & 129 \\
\hline
\end{tabular}

Sumber: Diolah dari Data Primer, 2016

\section{Persepsi Petani terhadap Peran Penyuluh mengenai Hasil Inovasi (ide baru) Penyuluh dapat dengan Mudah Terlihat}

Tabel 25 menunjukan bahwa sebagian besar responden, yaitu $24(66,6 \%)$ setuju, diikuti masing-masing $6(16,6 \%)$ responden yang sangat setuju dan ragu-ragu bahwa hasil inovasi penyuluh dapat dengan mudah terlihat. Dalam indikator ini, total skor persepsi petani sebesar $144 / 180 \times 100 \%=80 \%$, sehingga interpretasi nilainya tergolong baik. Hal yang melatarbelakangi persepsi petani baik terhadap peran penyuluh dalam hal ini hasil inovasi penyuluh dapat dengan mudah terlihat adalah menurut wawancara saya dengan para petani di lapangan karna petani mengikuti saran atau ide baru dari penyuluh hasil-hasil pertanian mereka bisa dengan mudah terlihat atau meningkat.

\section{Persepsi Petani terhadap Peran Penyuluh mengenai Penggunaan Inovasi Penyuluh dan Hasilnya dapat Mudah Diamati}

Tabel 26 menunjukan bahwa sebagian besar responden, yaitu $25(69,4 \%)$ setuju, diikuti 6 $(16,6 \%)$ yang sangat setuju dan 5 (13,8\%) responden masih ragu-ragu bahwa penggunaan inovasi penyuluh dan hasilnya dapat dengan mudah diamati. Dalam indikator ini, total skor persepsi petani sebesar $145 / 180 \times 100 \%=80,5 \%$, sehingga interpretasi nilainya tergolong baik. Menurut wawancara saya di lapangan hal yang melatarbelakangi persepsi petani baik terhadap peran penyuluh dalam hal ini penggunaan inovasi penyuluh dan hasilnya dapat dengan mudah diamati adalah karna dengan penggunaan inovasi penyuluh pertanian petani bisa dengan mudah mengamati hasil pertanian atau dapat membedakan contoh misalnya waktu panen lalu hanya beberapa karung sekarang mangalami peningkatan hampir 2 kali lipat.

\section{Persepsi Petani terhadap Peran Penyuluh mengenai Dengan Penggunaan inovasi Penyuluh dapat Meningkatkan Pendapatan Petani}

Tabel 27 menunjukan bahwa sebagian besar responden, yaitu $18(50 \%)$ setuju, diikuti 12 $(33,3 \%)$ sangat setuju serta $6(16,6 \%)$ responden yang masih merasa ragu-ragu bahwa dengan penggunaan inovasi penyuluh dapat meningkatkan pendapatan petani. Dalam indikator ini, total skor persepsi petani sebesar 150/180 x $100 \%=83,3 \%$, sehingga interpretasi nilainya tergolong sangat baik. Hal yang melatarbelakangi persepsi petani sangat baik terhadap peran penyuluh pertanian yaitu mereka mengatakan bahwa dengan mereka menggunakan saran, 
inovasi atau ide baru dari penyuluh pertanian pendapatan mereka meningkat.

\section{Persepsi Petani terhadap Peran Penyuluh mengenai Pendapatan tersebut Lebih Besar dari Sebelum Petani Menggunakan inovasi Penyuluh Pertanian}

Tabel 28 menunjukan bahwa sebagian besar responden, yaitu $21(58,3 \%)$ setuju, diikuti 9 $(25 \%)$ sangat setuju serta $3(8,3 \%)$ responden masih ragu-ragu diikuti $2(5,5 \%)$ responden yang tidak setuju dan $1(2,7 \%)$ yang sangat tidak setuju bahwa pendapatan tersebut lebih besar dari sebelum petani menggunakan inovasi penyuluh pertanian. Dalam indikator ini, total skor persepsi petani sebesar 143/180 x 100\% =79,4\%, sehingga interpretasi nilainya tergolong baik. Hal yang melatarbelakangi persepsi petani baik terhadap peran penyuluh pertanian dalam hal ini pendapatan yang didapat petani lebih besar dari sebelum petani menggunakan inovasi penyuluh pertanian adalah menurut petani setelah mereka menggunakan saran atau inovasi dari penyuluh pertanian pendapatan atau produksi hasil-hasil pertanian mereka meningkat dari sebelum mereka menggunakan saran atau inovasi dari penyuluh pertanian.

Tabel 24 Tingkat Kemudahan Inovasi Penyuluh Dapat dengan Mudah Dipraktekkan

\begin{tabular}{|c|c|c|c|}
\hline Alternatif & Alternatif & Jumlah & Persentase \\
\hline Jawaban & Skor & $\begin{array}{r}\text { Responden } \\
\text { (orang) }\end{array}$ & $\begin{array}{c}\text { Responden } \\
(\%)\end{array}$ \\
\hline
\end{tabular}

\begin{tabular}{ccccc}
\hline Sangat Setuju & 5 & 10 & 27,7 & 50 \\
Setuju & 4 & 20 & 55,5 & 80 \\
Ragu-Ragu & 3 & 6 & 16,6 & 18 \\
Tidak Setuju & 2 & - & - & - \\
Sangat Tidak Setuju & 1 & - & - & - \\
\hline Total & & 36 & 100 & 148 \\
\hline
\end{tabular}

Sumber: Diolah dari Data Primer, 2016

Tabel 25 Hasil Inovasi (ide baru) Penyuluh dapat dengan Mudah Terlihat

\begin{tabular}{ccccc}
\hline $\begin{array}{c}\text { Alternatif } \\
\text { Jawaban }\end{array}$ & $\begin{array}{c}\text { Alternatif } \\
\text { Skor }\end{array}$ & $\begin{array}{c}\text { Jumlah } \\
\text { Responden } \\
\text { (orang) }\end{array}$ & $\begin{array}{c}\text { Persentase } \\
\text { Responden } \\
(\%)\end{array}$ & $\begin{array}{c}\text { Total } \\
\text { Skor }\end{array}$ \\
\hline Sangat Setuju & 5 & 6 & 16,6 & 30 \\
Setuju & 4 & 24 & 66,6 & 96 \\
Ragu-Ragu & 3 & 6 & 16,6 & - \\
Tidak Setuju & 2 & - & - & - \\
Sangat Tidak Setuju & 1 & - & 100 & 144 \\
\hline
\end{tabular}

Sumber: Diolah dari Data Primer, 2016

Tabel 26 Penggunaan Inovasi Penyuluh dan Hasilnya dapat Mudah Diamati

\begin{tabular}{ccccc}
\hline $\begin{array}{c}\text { Alternatif } \\
\text { Jawaban }\end{array}$ & $\begin{array}{c}\text { Alternatif } \\
\text { Skor }\end{array}$ & $\begin{array}{c}\text { Jumlah } \\
\text { Responden } \\
\text { (orang) }\end{array}$ & $\begin{array}{c}\text { Persentase } \\
\text { Responden } \\
(\%)\end{array}$ & $\begin{array}{c}\text { Total } \\
\text { Skor }\end{array}$ \\
\hline Sangat Setuju & 5 & 6 & 16,6 & 30 \\
Setuju & 4 & 25 & 69,4 & 100 \\
Ragu-Ragu & 3 & 5 & 13,8 & 15 \\
Tidak Setuju & 2 & - & - & - \\
Sangat Tidak Setuju & 1 & - & - & - \\
\hline Total & & 36 & 100 & 145
\end{tabular}

Sumber: Diolah dari Data Primer, 2016 
Tabel 27 Dengan Penggunaan inovasi Penyuluh dapat Meningkatkan Pendapatan Petani

\begin{tabular}{ccccc}
\hline $\begin{array}{c}\text { Alternatif } \\
\text { Jawaban }\end{array}$ & $\begin{array}{c}\text { Alternatif } \\
\text { Skor }\end{array}$ & $\begin{array}{c}\text { Jumlah } \\
\text { Responden } \\
\text { (orang) }\end{array}$ & $\begin{array}{c}\text { Persentase } \\
\text { Responden } \\
(\%)\end{array}$ & $\begin{array}{c}\text { Total } \\
\text { Skor }\end{array}$ \\
\hline Sangat Setuju & 5 & 12 & 33,3 & 60 \\
Setuju & 4 & 18 & 50 & 72 \\
Ragu-Ragu & 3 & 6 & 16,6 & 18 \\
Tidak Setuju & 2 & - & - & - \\
Sangat Tidak Setuju & 1 & - & - & - \\
\hline Total & & 36 & 100 & 150
\end{tabular}

Sumber: Diolah dari Data Primer, 2016

Tabel 28 Pendapatan tersebut Lebih Besar dari Sebelum Petani Menggunakan inovasi Penyuluh Pertanian

$\begin{array}{ccccc}\text { Alternatif } & \text { Alternatif } & \text { Jumlah } & \text { Persentase } & \text { Total } \\ \text { Jawaban } & \text { Skor } & \text { Responden } & \text { Responden } & \text { Skor }\end{array}$

(orang) $\quad(\%)$

\begin{tabular}{ccccc}
\hline Sangat Setuju & 5 & 9 & 25 & 45 \\
Setuju & 4 & 21 & 58,3 & 84 \\
Ragu-Ragu & 3 & 3 & 8,3 & 9 \\
Tidak Setuju & 2 & 2 & 5,5 & 4 \\
Sangat Tidak Setuju & 1 & 1 & 2,7 & 1 \\
\hline Total & & 36 & 100 & 143 \\
\hline
\end{tabular}

Sumber: Diolah dari Data Primer, 2016

Tabel 29 Rekapitulasi Jumlah Skor pengambilan data, Indeks persepsi, dan interpretasi pada indikator persepsi tentang tingkat kemudahan untuk dilihat hasilnya (observability)

\begin{tabular}{lllll}
\hline No & \multicolumn{1}{c}{ Pernyataan } & $\begin{array}{c}\text { Total } \\
\text { Skor }\end{array}$ & $\begin{array}{c}\text { Indeks } \\
\text { Persepsi (\%) }\end{array}$ & Interpretasi \\
\hline 1 & $\begin{array}{l}\text { Tingkat kemudahan inovasi penyuluh dapat } \\
\text { dengan mudah dipraktekkan }\end{array}$ & 148 & 82,2 & Sangat Baik \\
2 & $\begin{array}{l}\text { Hasil inovasi penyuluh dapat dengan mudah } \\
\text { terlihat }\end{array}$ & 144 & 80 & Baik \\
3 & $\begin{array}{l}\text { Penggunaan inovasi penyuluh dan hasilnya } \\
\text { dapat mudah diamati }\end{array}$ & 145 & 80,5 & Baik \\
4 & $\begin{array}{l}\text { Dengan penggunaan inovasi penyuluh dapat } \\
\text { meningkatkan pendapatan petani }\end{array}$ & 150 & 83,3 & Sangat Baik \\
\hline 5 & $\begin{array}{l}\text { Pendapatan tersebut lebih besar dari sebelum } \\
\text { petani menggunakan inovasi penyuluh } \\
\text { pertanian }\end{array}$ & 143 & 79,4 & Baik \\
\hline Sumber Digla & & &
\end{tabular}

Sumber: Diolah dari data primer, 2016

Rekapitulasi Persepsi Petani Terhadap Tingkat Kemudahan untuk Dilihat Hasilnya (Observability)

Tabel 29 Menunjukan 5 pernyataan tentang persepsi petani terhadap tingkat kemudahan untuk untuk dilihat hasilnya (observability) Pernyataan dengan jumlah indeks tertiggi adalah pernyataan 4 yaitu 83,3 selanjutnta pernytaan 1 yaitu 82,2 selanjutnya pernyataan 3 yaitu 80,5 selanjutnya pernyataan 2 yaitu 80 dan pernyataan 5 yaitu 79,4. 
Tabulasi Total Skor, Indeks Persepsi, Dan Interpretasi Nilai

Tabel 30 Tabulasi Total Skor, Indeks Persepsi, Dan Interpretasi Nilai

\begin{tabular}{|c|c|c|c|c|}
\hline No & Pernyataan & $\begin{array}{l}\text { Total } \\
\text { Skor }\end{array}$ & $\begin{array}{l}\text { Indeks } \\
\text { Persepsi }\end{array}$ & Interpretas \\
\hline 1 & $\begin{array}{l}\text { Petani mendapatkan ide baru guna untuk } \\
\text { diterapkan dalam usaha taninya }\end{array}$ & 165 & 91,6 & Sangat Baik \\
\hline 2 & $\begin{array}{l}\text { Ide baru tersebut dapat meningkatkan pendapatan } \\
\text { petani }\end{array}$ & 152 & 84,4 & Sangat Baik \\
\hline 3 & $\begin{array}{l}\text { Dengan meningkatnya pendapatan dapat juga } \\
\text { meningkatkan kesejahteraan petani }\end{array}$ & 162 & 90 & Sangat Baik \\
\hline 4 & $\begin{array}{l}\text { Dengan meningkatnya kesejahteraan petani bisa } \\
\text { menyekolahkan anak }\end{array}$ & 160 & 88,8 & Sangat Baik \\
\hline 5 & $\begin{array}{l}\text { Dengan meningkatnya pendapatan bapak atau ibu } \\
\text { bisa membuat tabungan (saving) untuk keluarga }\end{array}$ & 149 & 82,7 & Sangat Baik \\
\hline 6 & $\begin{array}{l}\text { Inovasi (ide baru) yang di berikan } \\
\text { penyuluh sesuai dengan harapan petani }\end{array}$ & 151 & 83,8 & Sangat Baik \\
\hline 7 & $\begin{array}{l}\text { Inovasi yang diberikan penyuluh dapat } \\
\text { disesuaikan dengan adat kebiasaan yang ada pada } \\
\text { petani }\end{array}$ & 144 & 80 & Baik \\
\hline 8 & $\begin{array}{l}\text { Inovasi yang diberikan penyuluh dapat memenuhi } \\
\text { harapan petani }\end{array}$ & 148 & 82,2 & Sangat Baik \\
\hline 9 & $\begin{array}{l}\text { Harapan petani tersebut apakah bisa membangun } \\
\text { tempat tinggal (rumah) }\end{array}$ & 145 & 80,5 & Baik \\
\hline 10 & $\begin{array}{l}\text { Tempat tinggal tersebut sesuai dengan ekspektasi } \\
\text { petani (harapan petani) }\end{array}$ & 150 & 83,3 & Sangat Baik \\
\hline 11 & Petani sulit memahami inovasi penyuluh & 106 & 58,8 & Kurang Baik \\
\hline 12 & $\begin{array}{l}\text { Dalam prakteknya inovasi penyuluh lebih sulit } \\
\text { dilakukan oleh petani }\end{array}$ & 138 & 76,6 & Baik \\
\hline 13 & $\begin{array}{l}\text { Inovasi penyuluh (mesin-mesin) lebih mudah } \\
\text { dibanding dengan cara penggunaan alat-alat } \\
\text { tradisional }\end{array}$ & 152 & 84,4 & Sangat Baik \\
\hline 14 & $\begin{array}{l}\text { Penggunaan mesin pertanian bisa mempercepat } \\
\text { pekerjaan petani }\end{array}$ & 161 & 89,4 & Sangat Baik \\
\hline 15 & $\begin{array}{l}\text { Dengan menggunakan mesin pertanian petani bisa } \\
\text { menghemat waktu dan biaya }\end{array}$ & 156 & 86,6 & Sangat Baik \\
\hline 16 & Petani mau mencoba inovasi penyuluh pertanian & 148 & 82,2 & Sangat Baik \\
\hline 17 & $\begin{array}{l}\text { Petani bisa dengan mudah mencoba inovasi } \\
\text { penyuluh pertanian }\end{array}$ & 144 & 80 & Baik \\
\hline 18 & $\begin{array}{l}\text { Dalam prakteknya inovasi penyuluh mudah } \\
\text { dilakukan oleh petani }\end{array}$ & 145 & 80,5 & Baik \\
\hline 19 & $\begin{array}{l}\text { Tingkat kemudahan inovasi penyuluh mudah } \\
\text { dicoba oleh petani }\end{array}$ & 143 & 79,4 & Baik \\
\hline 20 & $\begin{array}{l}\text { Dengan kemudahan inovasi penyuluh pertanian } \\
\text { bisa membuat petani menggunakan inovasi } \\
\text { (mesin-mesin) tersebut terus-menerus }\end{array}$ & 129 & 71,6 & Baik \\
\hline 21 & $\begin{array}{l}\text { Tingkat kemudahan inovasi penyuluh dapat } \\
\text { dengan mudah dipraktekkan }\end{array}$ & 148 & 82,2 & Sangat Baik \\
\hline 22 & $\begin{array}{l}\text { Hasil inovasi penyuluh dapat dengan mudah } \\
\text { terlihat }\end{array}$ & 144 & 80 & Baik \\
\hline 23 & $\begin{array}{l}\text { Penggunaan inovasi penyuluh dan hasilnya dapat } \\
\text { mudah diamati }\end{array}$ & 145 & 80,5 & Baik \\
\hline 24 & $\begin{array}{l}\text { Dengan penggunaan inovasi penyuluh dapat } \\
\text { meningkatkan pendapatan petani }\end{array}$ & 150 & 83,3 & Sangat Baik \\
\hline 25 & $\begin{array}{l}\text { Pendapatan tersebut lebih besar dari sebelum } \\
\text { petani menggunakan inovasi penyuluh pertanian }\end{array}$ & 143 & 79,4 & Baik \\
\hline
\end{tabular}

Sumber: Diolah dari Data Primer, 2016 
Cara perhitungan skor keseluruhan untuk mengetahui tingkat persepsi petani terhadap peran penyuluh :

\section{Jumlah Skor Seluruh Kriterium = Capaian Jumlah Skor $\mathbf{X}$ Jumlah Responden $\mathbf{X}$ Jumlah Pertanyaan}

Untuk :

$\mathrm{S}_{5}=5 \times 36=180 \times 25=4500$

$\mathrm{S}_{4}=4 \times 36=144 \times 25=3600$

$\mathrm{S}_{3}=3 \times 36=108 \times 25=2700$

$\mathrm{S}_{2}=2 \times 36=72 \times 25=1800$

$\mathrm{S}_{1}=1 \times 36=36 \times 25=900$

Jumlah skor ideal untuk keseluruhan pertanyaan $=4500$ (Sangat setuju), sedangkan Jumlah skor terendah adalah 900 (Sangat tidak setuju), berdasarkan data yang dihimpun dari sebanyak 25 indikator berupa instrument pernyataan yang diajukan kepada 36 responden petani, maka diperoleh total skor 3678, dengan letak indeks persepsi petani di tentukan berdasarkan skala likert berikut :

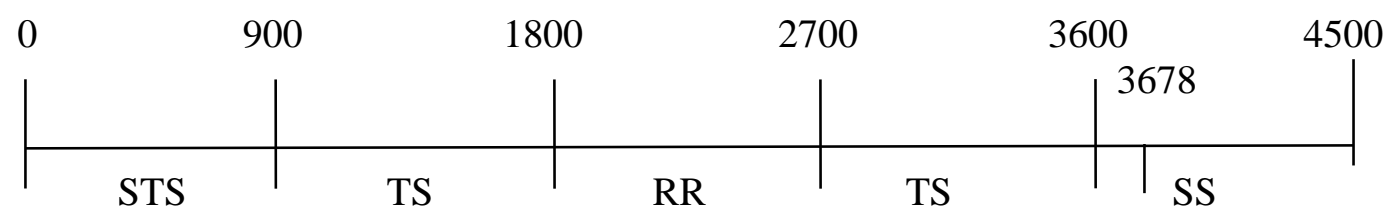

Analisis data yang digunakan merupakan analisis deskriptif yang dianalisis dengan menggunakan skala likert (likert scale) dimana menurut Riduwan dalam buku rumus dan data dalam analisis statistika sebagai berikut:

Tingkat Persepsi Petani $=\frac{\text { JumlahSkorHasilPengumpulanData }}{\text { JumlahSkorIdeal }(\text { tertinggi })} \times 100 \%$

Tingkat Persepsi Petani $=\frac{3678}{4500} \times 100 \%=81 \%$

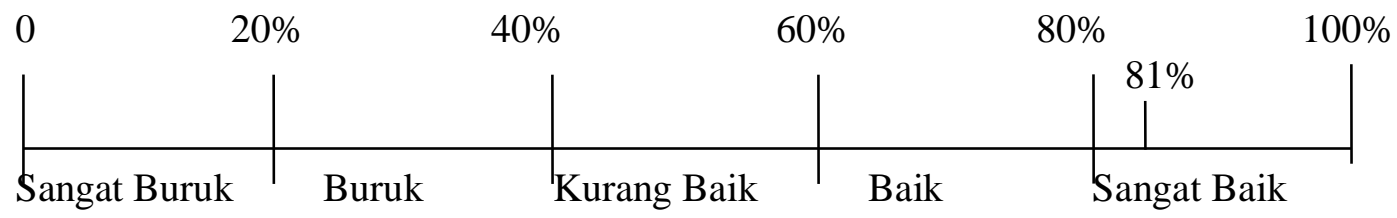

Berdasarkan hasil analisis menggunakan Skala Likert, maka dapat diketahui bahwa angka indeks tingkat persepsi petani di Desa Rasi mengenai peran penyuluh pertanian adalah sebesar $81 \%$ dan tergolong sangat baik.

Hasil wawancara mendalam kepada petani di Desa Rasi menunjukan faktor yang menyebabkan persepsi petani sangat baik kepada penyuluh pertanian. Petani beranggapan bahwa dengan penggunan saran, inovasi, ide baru dari penyuluh pertanian yang ada di Desa Rasi pendapatan mereka meningkat atau produksi hasil pertanian para petani meningkat dari sebelum mereka menggunakan saran penyuluh atau inovasi penyuluh pertanian.

Faktor lain yang menyebabkan persepsi petani sangat baik terhadap peran penyuluh pertanian yang ada di Desa Rasi adalah para petani bisa dengan mudah memperoleh bantuan berupa pupuk, obatobatan dan mesin-mesin pertanian lewat parah penyuluh pertanian melalui program GPPTT (gerakan program pelayanan tanaman terpadu) dari Dinas Pertanian Kabupaten Minahasa Tenggara dan Provinsi Sulawesi Utara. 


\section{KESIMPULAN DAN SARAN}

\section{Kesimpulan}

Hasil penelitian ini menunjukan bahwa:

1. Berdasarkan hasil analisis menggunakan skala likert, diketahui total skor tingkat persepsi petani di Desa Rasi mengenai peran penyuluh pertanian sebesar 3678 dan berada pada indeks persepsi $81 \%$, sehingga persepsi petani tergolong sangat baik.

2. Indikator persepsi petani yang dianggap sangat baik mengenai peran penyuluh, yaitu pada indikator pemakaian inovasi penyuluh dapat meningkatkan pendapatan dan kesejahteraan petani, serta persepsi petani mengenai kecocokan, peran (inovasi penyuluh) dapat disesuaikan dengan adat istiadat dan kebiasaan yang ada pada petani, tingkat kerumitan dalam prakteknya inovasi penyuluh lebih sulit dilakukan, inovasi penyuluh (mesin-mesin) lebih mudah dibanding dengan cara penggunaan alat-alat tradisional, serta dengan menggunakan mesin pertanian, petani bisa menghamat waktu dan biaya, persepsi petani sangat baik.

3. Persepsi petani tergolong sangat baik juga pada indikator peningkatan produktifitas hasil, tingkat kemudahan inovasi penyuluh dapat dengan mudah dipraktekkan, hasil inovasi penyuluh dapat dengan mudah terlihat atau diamati, produktifitas hasil yang meningkat tersebut lebih besar dari sebelum petani menggunakan inovasi penyuluh pertanian.

\section{Saran}

Persepsi petani terhadap peran penyuluh sangat baik, sehingga yang diperlukan sekarang tinggal menjaga atau lebih ditingkatkan lagi kinerja penyuluh pertanian yang ada di Desa Rasi ini, sehingga petani bisa lebih meningkatkan lagi produksi hasil-hasil pertanian, sehingga dapat meningkatkan pendapatan, serta tingkat ksejahteraan keluarga petani tetap terjaga.

\section{DAFTAR PUSTAKA}

A.W \& H.S. Hawkins, 1999. Penyuluhan Pertanian. Penerbit Kanisius, Yogyakarta.

Darmaludin, S. Suwasono dan RE.Muljawan 2012, Peranan Penyuluh Pertanian Dalam Penguatan Usaha Tani Bawang Daun di Kecamatan Sukapura Kabupaten Probolinggo. Ejournal ( di akses 7 februari 2016 )

Dendegau.M.M, 2013. Persepsi Petani Sayuran Dataran Tinggi terhadap Pestisida Organik di Kelurahan Rurukan Kecamatan Tomohon Timur. Skripsi S1. Jurusan Sosial Ekonomi Fakultas Pertanian Universitas Sam Ratulangi Manado.

Departemen Pertanian, 2006.Undang-Undang Republik Indonesia nomor 16 tentang Sistem Penyuluhan Pertanian, Perikanan dan Kehutanan, Jakarta.

Departemen Pertanian, Undang-Undang Republik Indonesia Nomor 273 Tahun 2007, Tentang Sistem Penyuluhan Pertanian, Perikanan dan Kehutanan, Jakarta.

Edwina, S dan Evi Maharani 2010.Persepsi Petani Terhadap Teknologi Pengolahan Pakan di Kecamatan Kerinci Kanan Kabupaten Siak.Indonesian Journal of Agricultural Economics (IJAE) Volume 2, Nomor 1, Desember 2010, ISSN 2087 409X. ( diakses rabu 30 maret 2016 ).

Kartasapoetra, 1994. Teknologi Penyuluhan Pertanian. Penerbit Bumi Aksara, Jakarta.

Kusnadi, D. 2011. Metode Penyuluhan Pertanian. Penerbit STPP Press. Bogor.

Malinau. S. 2011. Peranan Kelompok Tani. http://kumpulanbungamawarku, (diakses 7 februari 2016 )

Mardikanto, Totok. 2005. Metode dan Teknik Penyuluhan Pertanian. Penerbit Prima Theresia Pressindo. Surakarta.

Marliati, Sumardjo, Pang S. Asngari, Prabowo Tjitropranoto dan Asep Saefuddin. 2008, Faktor-faktor Penentu Peningkatan Kinerja Penyuluh Pertanian dalam Memberdayakan Petani.(Kasus di Kabupaten Kampar Provinsi Riau). Jurnal Penyuluhan. September. Vol. 4 No. 2 93.( diakses rabu 30 maret 2016 ) 
Mosher, A.T. 1997.Menggerakkan dan Membangun Pertanian. Penerbit CV. Yasaguna. Jakarta.

Mujianingsi, 2013. Hubungan Persepsi Ibu Tentang Kolostrum Dengan pemberian Kolostrum Pada Bayi Di Desa MLILIR Kecamatan Bandungan Kabupaten Semarang. Ejurnal ( diakses rabu 30 maret 2016 ).

Riduwan. 2008. Rumus dan Data dalam Analisis Statistika. Penerbit Alphabet. Bandung.

Riduwan.2003. Skala Pengukuran VariabelVariabel Penelitian. CV. Alfabeta. Surabaya.

Riduwan.2012.Rumus dan data dalam analisis statistika. Penerbit alphabet.bandung.

Rogers, E.M. 1983. Diffution of Innovations. The Free Press, New York.

Sajogyo. 1999. Memacu Perekonomian Rakyat. Penetbit Aditya Media.Jakarta

Setiadi. Nugroho.,2010. Perilaku Konsumen. Kencana media group jl.tamba raya No.23 Rawamangun - Jakarta 13220.

Slamet, Margono. 2003. Pemberdayaan Masyarakat. Dalam Membentuk Pola Perilaku Manusia Pembangunan. Penyunting: Ida Yustina dan Ajat Sudrajat, 45 - 48. Bogor: IPB Press.

Slamet, Margono. 2003. Pemberdayaan Masyarakat. Dalam Membentuk Pola Perilaku Manusia Pembangunan. Penyunting: Ida Yustina dan Ajat Sudrajat, 45 - 48. Bogor: IPB Press.

Subagio H. 2008 (Disertasi). Peran Kapasitas Petani Dalam Mewujudkan Keberhasilan Usaha Tani, Program Pascasarjana.Bogor: Institut Pertanian Bogor. (di akses 14 april 2016)
Sugiyono. 2011.Metode Penelitian Administrasi dan R \& D. Penerbit Alfabeta. Bandung.

Sumardjo, Saharuddin, dan, Nuning, Kusumowardani. 2003. Pendampingan dalam Rangka Pemberdayaan Kelembagaan Lumbung Pangan. (Laporan Akhir). Bogor: Bagian Proyek Pengembangan Ketahanan Pangan Masyarakat Badan Bimas Ketahanan angan dan Pusat Studi Pemba-ngunan LP-IPB.

Sunaryo. (2004). Psikologi Untuk Keperawatan. Penerbit EGC. Jakarta.

Sunyoto. Danang. 2014.Praktik Riset Perilaku Konsumen.CAPS (center of academic publishing services. Jl. Cempaka putih No.8. Yogyakarta)

Sunyoto. Danang.2012. Konsep Dasar Riset Pemasaran \& Perilaku Konsumen.

Suriatna, Sumardi. 1988.Metode Penyuluhan/Sumardi Suriatna - Cet.1 Jakarta: Medyatama, Sarana Perkasa.Hlm. 19

Swasta. 2000. Konsep Pengukuran Persepsi. Penerbit Grafindo Utama. Jakarta.

Syaiful.Rahman. 2009. Penumbuhan Kelompok Tani. http:bapeluh. Blogspot.com /2009/06 penumbuhan kelompok tani poktan.Html. (diakses 7 februari 2016.

Van den Ban \& A.W Hawkins. 2012, Penyuluhan Pertanian. Penerbit Kanisius.Yogyakarta. 